\title{
USO DE CARRAGENAS NA FABRICAÇÃO DO QUEIJO TIPO MINAS FRESCAL
}

\author{
ADRIANA ROCHA BOGHOSSIAN \\ Engenheira Agrônoma
}

Orientador: Prof. Dr. JOSÉ LEONARDO ETORE DO VALLE

\begin{abstract}
Dissertação apresentada à Escola Superior de Agricultura "Luiz de Queiróz", da Universidade de São Paulo, para obtenção do título de Mestre em Ciências. Área de concentração: Ciência e Tecnologia de Alimentos.
\end{abstract}

PIRACICABA

Estado de São Paulo- Brasil

Novembro de 1995 
Dados Internacionais de Catalogação na Publicação (CIP)

DIVISÃO DE BIBLIOTECA E DOCUMENTAÇẨO - Campus “Luiz de Queiroz"/usP

Boghossian, Adriana Rocha

Uso de carragenas na fabricação do queijo tipo minas frescal. Piracicaba, 1995.

$91 \mathrm{p}$.

Diss.(Mestre) - ESALQ

Bibliografia.

1. Colóide em queijo minas frescal 2. Queijo minas frescal 3. Queijo minas frescal Durabilidade 1. Escola Superior de Agricultura Luiz de Queiroz, Piracicaba

CDD 637.353

664.06 


\title{
USO DE CARRAGENAS NA FABRICAÇÃO DO QUEIJO TIPO MINAS FRESCAL
}

\author{
ADRIANA ROCHA BOGHOSSIAN
}

Aprovada em: 15/01/96

Comissão Julgadora:

Prof. Dr. Antonio Joaquim de Oliveira - ESALQ/USP

Prof. Dr. José Leonardo Etore do Valle - ITAL

Dr. Lúcio Alberto Forti Antunes - "Chr. Hansen"

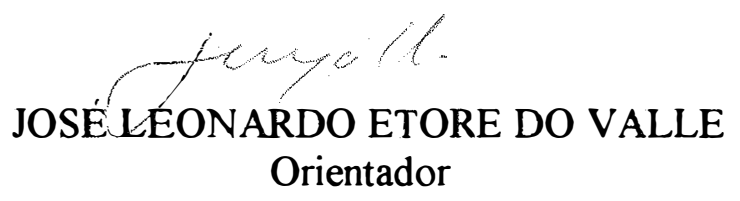




\title{
À Deus, pela presença constante em meu coração Agradeço
}

Aos meus pais e irmãos Ofereço

\author{
À Irene \\ Dedico
}




\section{AGRADECIMENTOS}

Agradeço a todos aqueles que de alguma forma contribuíram para a realização deste trabalho, especialmente:

Ao Prof. Dr. José Leonardo Etore do Valle, pela sabedoria na orientação, pela objetividade e simplicidade na condução do trabalho e pelo constante bom humor que tornou tudo mais fácil e agradável.

À CAPES, pela concessão da bolsa de estudo.

À Escola Superior de Agricultura "Luiz de Queiróz", de modo particular ao Departamento de Ciência e Tecnologia Agroindustrial, seus professores e funcionários, pelas facilidades oferecidas para a execução deste trabalho.

À Germantown do Brasil e à Sanofi (SBI) do Brasil, pelo fornecimento da matéria prima.

Aos amigos Marta Regina Verruma e Alberto, pela incomparável ajuda prestada em todos os momentos e principalmente pela análise estatística dos dados.

Ao Prof. Dr. Antônio Joaquim de Oliveira, ao Prof. Dr. Luiz Eduardo Gutierrez, à Cleomar Maria de Carvalho e a Carlos Eduardo Garcia, pela agradável convivência e colaboração.

Às bibliotecárias Beatriz e Midiam, pelo auxílo e organização das referências bibliográficas.

À Débora Regina Pinton, por sua amizade e pela colaboração prestada para os ajustes finais e impressão deste trabalho.

À Prof. Dra. Mônica Fulchieri e ao Prof. Dr. Yaakov Okon, por me servirem de exemplos a serem seguidos e por acreditarem em mim acima de qualquer outra coisa.

Aos amigos Mônica Sutton, Fabíola, Luciene, Jeferson, Teresa, Valéria, Samuel e Gabrielle, por tudo de tão valioso que me ensinaram, pelo amor da amizade e por estarem presentes não só nos momentos alegres mas também naqueles em que mais precisei de cada um e daquilo que cada um teve e sempre terá para compartilhar comigo por toda a vida. 


\section{SUMÁRIO}

\section{Página}

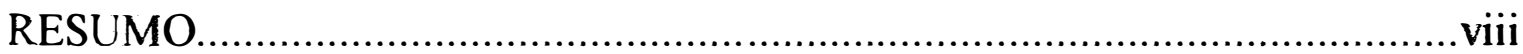

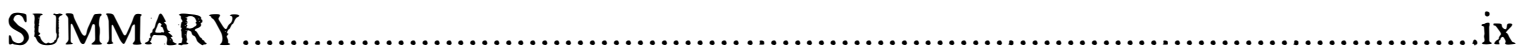

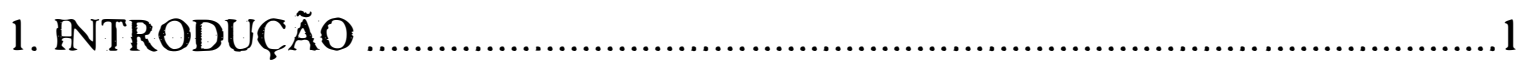

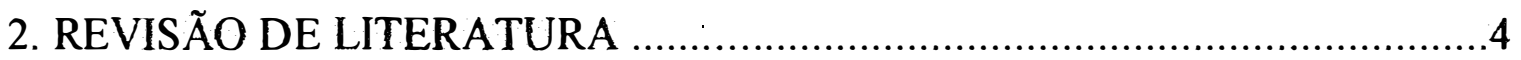

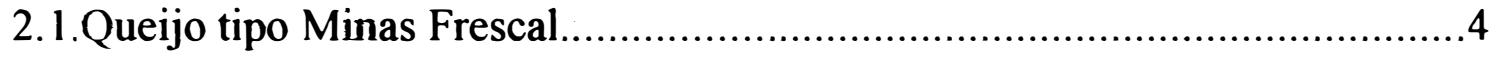

2.2. Controle da umidade na fabricação de queijos...........................................

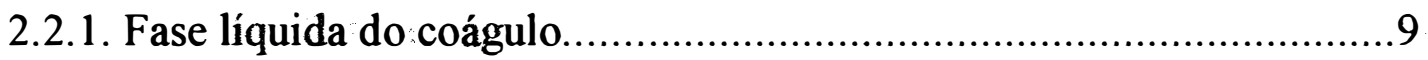

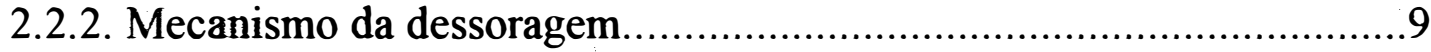

2.3. Processo da coagulação........................................................................ 10

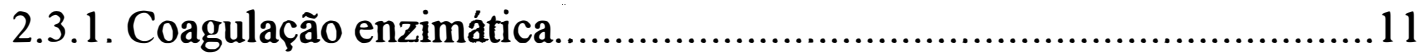

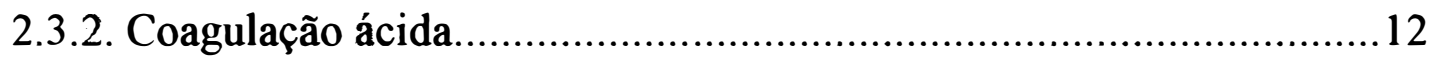

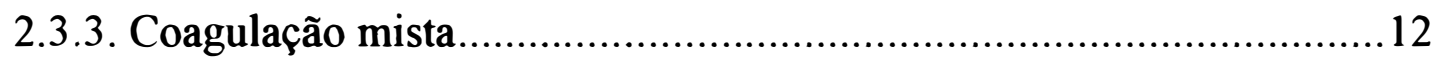

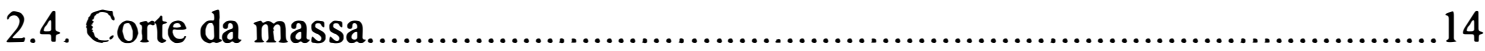

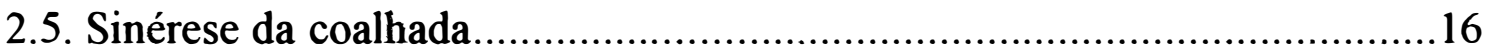

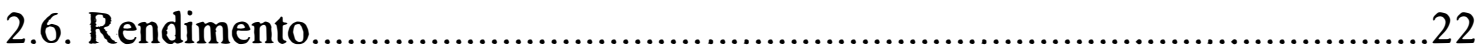

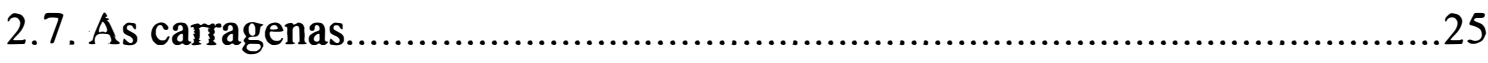

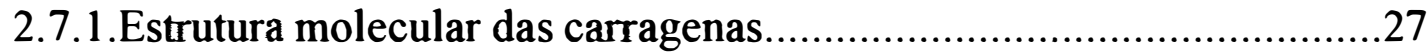

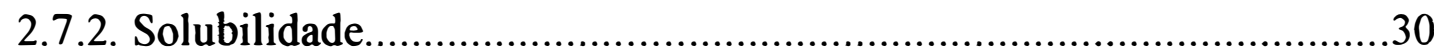

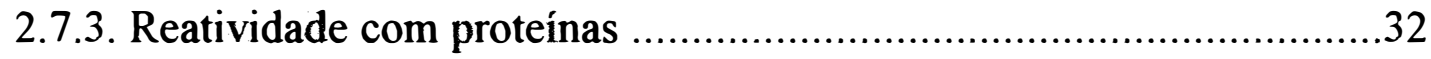

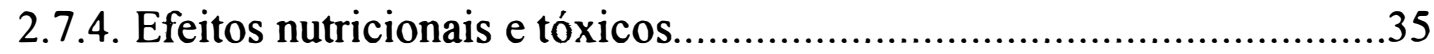

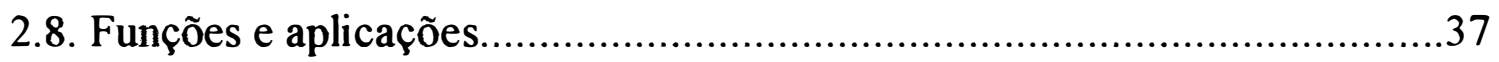

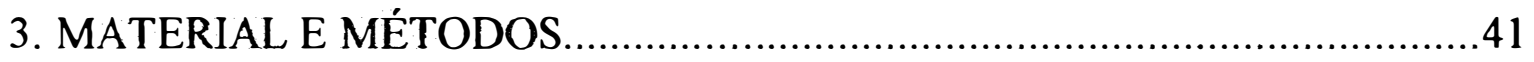

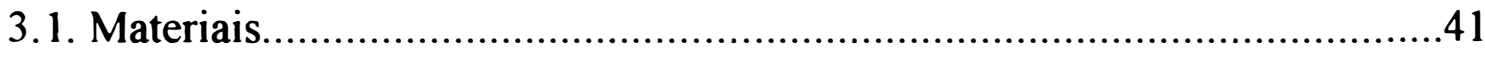

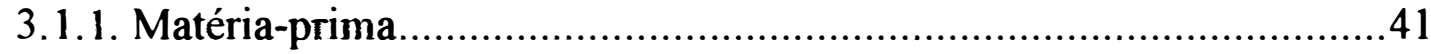

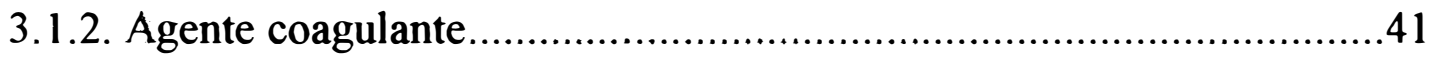




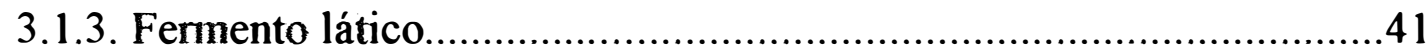

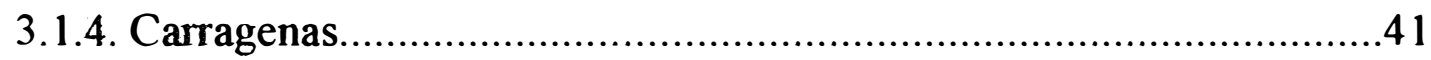

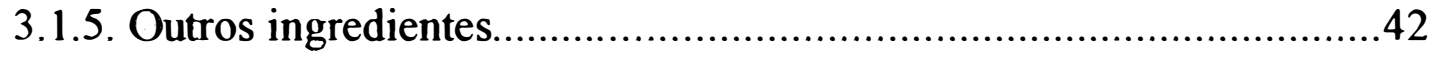

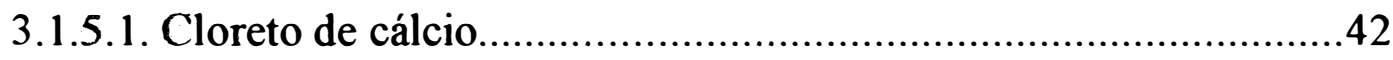

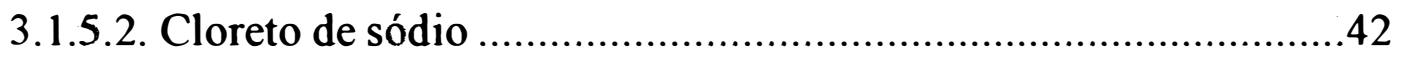

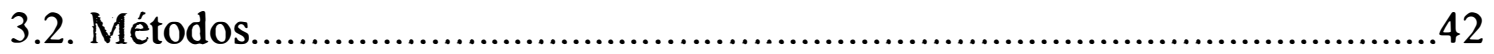

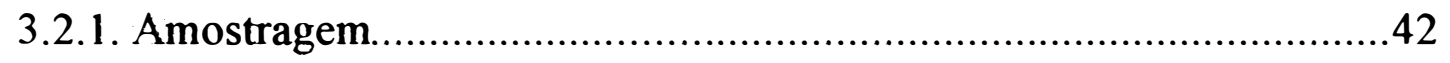

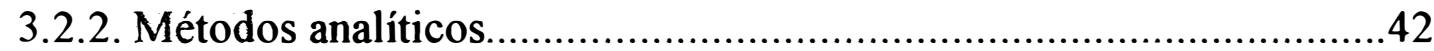

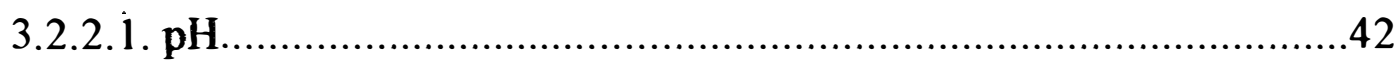

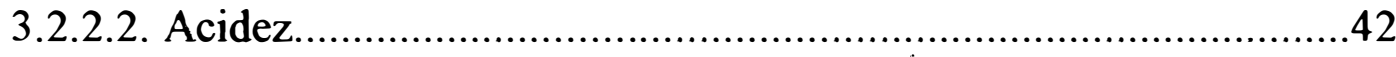

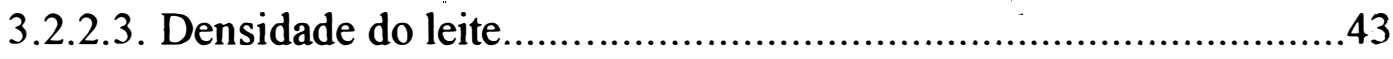

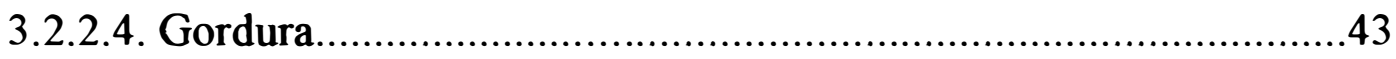

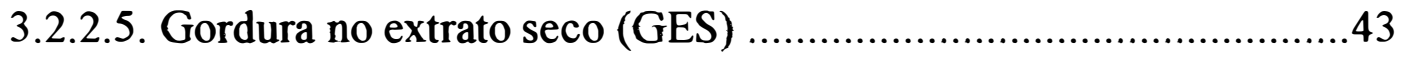

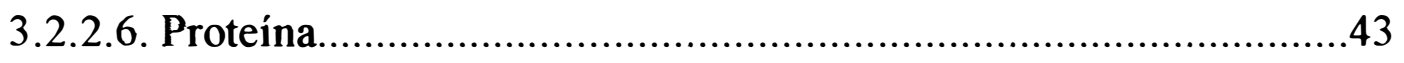

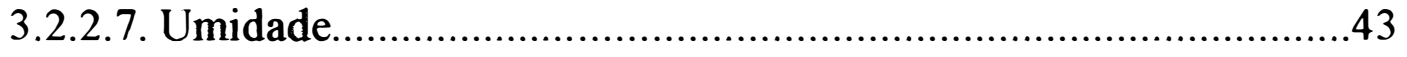

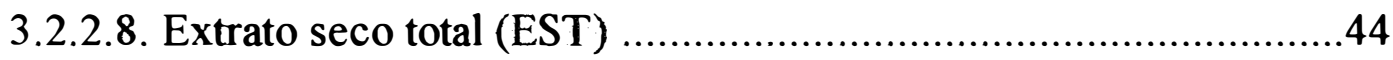

3.3. Elaboração do queijo Minas Frescal......................................................44

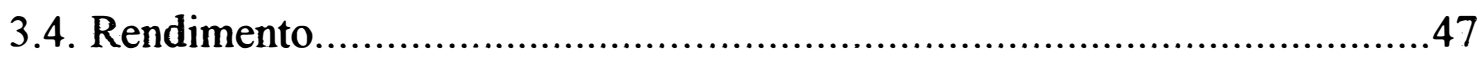

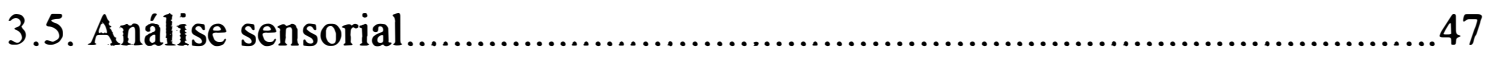

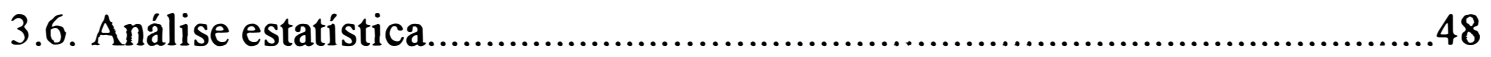

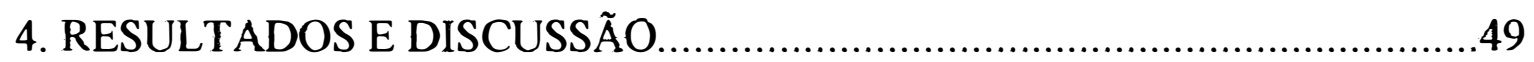

4.1. Características aparentes dos queijos....................................................49

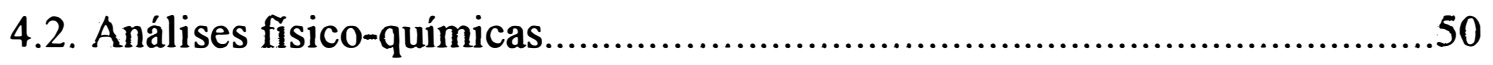

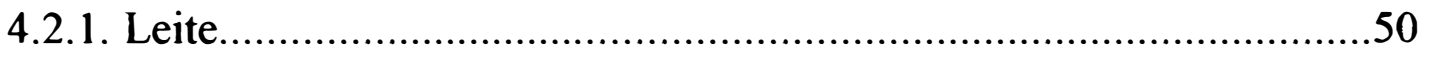

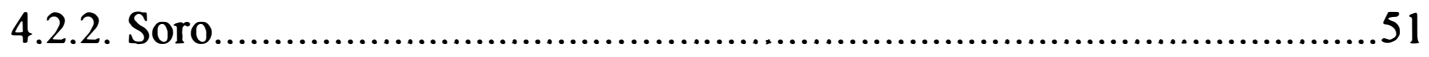

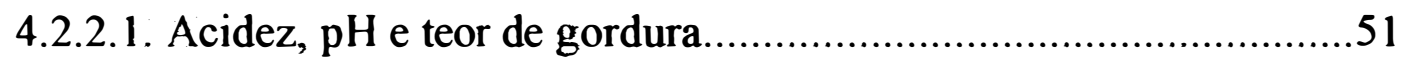

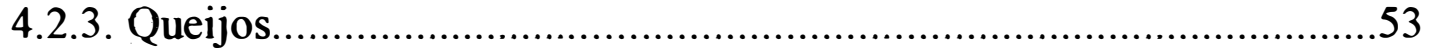

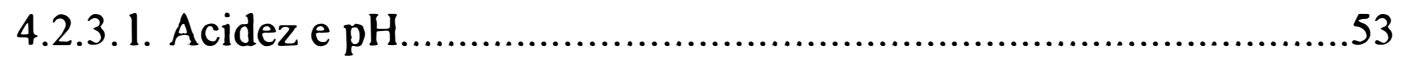




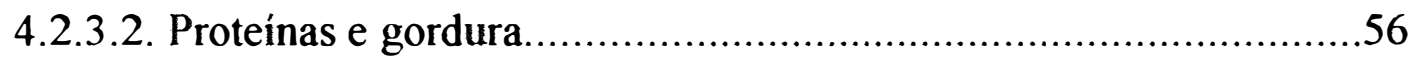

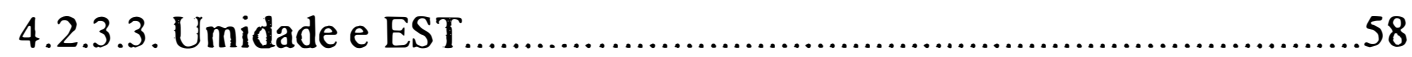

4.3. Rendimento

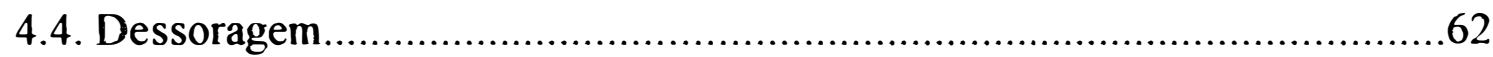

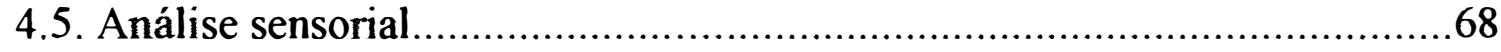

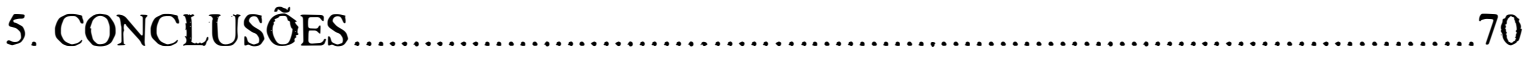

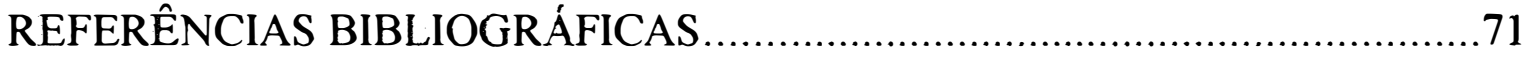

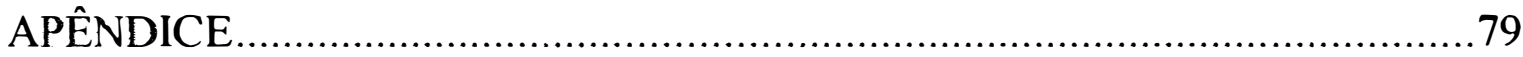




\section{LISTA DE FIGURAS}

\section{FIGURA N ${ }^{\circ}$}

Página

01 Estrutura básica de unidades de repetição das carragenas............................29

02 Interações iônicas entre carragenas e proteínas.........................................34

03 Fluxogramas de processsamento dos queijos pelos métodos tradicional e modificado.

04 Valores de $\mathrm{pH}$ dos queijos para os três tratamentos observados com 1 e 7 dias.

05 Valores de acidez dos queijos para os três tratamentos observados com 1 e 7 dias. 55

06 Rendimento dos queijos. 61

07 Perda de peso para os três tratamentos durante os 7 dias de armazenamento. 63

08 Perda de peso \% para os três tratamentos durante os 7 dias de armazenamento. .65 


\section{LISTA DE TABELAS}

TABELA N ${ }^{\circ}$

Página

01 Mercado mundial das carragenas.

02 Composição fisico-química do leite crú utilizado para a elaboração dos queijos. .50

03 Valores de $\mathrm{pH}$, acidez e gordura do soro após o corte da massa .51

04 Resultado das análises de acidez e pH dos queijos .53

05 Resultados das análises químicas dos queijos 56

06 Resultados das análises do teor de umidade e EST dos queijos. .59

07 Resultados de rendimento e peso dos queijos. .67

08 Equações de regressão e coeficientes de determinação entre perda de peso e os dias .67

09 Equações de regressão e coeficientes de determinação entre perda de peso \% e os dias. .67

10 Resultados da análise sensorial .68

11 Significância no teste triangular. 


\title{
USO DE CARRAGENAS NA FABRICAÇÃO DO QUEIJO TIPO MINAS FRESCAL
}

\author{
Autora: Adriana Rocha Boghossian \\ Orientador: Prof. Dr. José Leonardo Etore Do Valle
}

\section{RESUMO}

O queijo tipo Minas Frescal é um produto tipicamente brasileiro apresentando um alto rendimento de fabricação. É um produto bastante perecível devido ao seu alto teor de umidade, que afeta a manutenção da sua qualidade, rendimento e durabilidade, tendo uma vida de prateleira muito curta mesmo sob condições de refrigeração. A carragena, hidrocolóide extraído de algas marinhas, pela reatividade específica com as proteínas do leite e capacidade de reter umidade pode reduzir a sinérese, melhorar a textura e aumentar a firmeza dos queijos sem alterar seus padrões de qualidade. Foram avaliados dois processos, $o$ tradicional servindo como controle, e o modificado, com a utilização de duas diferentes carragenas para a elaboração dos queijos, estudando-se os parâmetros de natureza física, química e sensorial que afetaram a dessoragem, o rendimento e a aceitabilidade do queijo pelo consumidor. Os resultados deste estudo revelaram que pela utilização das carragenas: o processo de coagulação nem a atividade da cultura lática foram afetados; a composição dos queijos, principalmente em gordura e proteína mantiveram-se inalteradas mas levou a uma retenção de umidade (TRAD- 60,75\%, GE- 62,99\% e GEL- 61,55\%) significativamente maior nos queijos avaliados com 1 dia, e a um maior rendimento (GE- 17,09\% e GEL$16,18 \%$ ) em relação ao controle (TRAD- 16,07\%), com as características sensoriais dos queijos avaliados com 1 dia e após 7 dias de armazenamento a $10^{\circ} \mathrm{C}$ também mantendo-se inalteradas. 


\title{
UTILIZATION OF CARRAGEENANS IN THE MANUFACTURE OF MINAS FRESCAL TYPE CHEESE
}

\author{
Candidate: Adriana Rocha Boghossian \\ Adviser: Prof. Dr. José Leonardo Etore Do Valle
}

\section{SUMMARY}

Minas Frescal is a tipical brasilian cheese wich shows a high production yield. The quality stability, time of storage and yield are affected mainly by the high moisture level wich limits the shelf-life of this kind of cheese even under refrigerated conditions. The carrageenan, a hydrocolloid extracted from seaweeds, through its specific reactivity with milk proteins and capacity of moisture retention, can reduce syneresis, improve texture and body firmness of cheeses without affecting their quality patterns. Two diferent processings were evaluated, the traditional one as a control and the modified one with two carrageenans used for processing the cheeses. The influence of physico-chemical parameters that affected syneresis, yield and sensory acceptance were studied with the objective of improving quality of the cheese. From the results obtained in this study the following conclusions may be withdrawn from the utilization of carrageenans: coagulation process nor lactic culture activity were affected; cheese composition mainly in protein and fat content were not affected but induced to a moisture retention (TRAD- 60,75\%, GE- 62,99\% and GEL- 61,55\%) significantly higher in cheeses evaluated after 1 day and a higher yield (GE- 17,09\% and GEL$16,18 \%$ ) in relation to the control (TRAD- 16,07\%) and the sensorial cheese characteristics were not affected after 1 and 7 days of processing under refrigerated conditions. 


\section{INTRODUÇÃO}

O queijo é um dos alimentos de alto valor nutritivo, integrante da nossa dieta, com sabor agradável, existente em um grande número de variedades, com grande produção e consumo no mundo todo.

A fabricação de queijos no Brasil é de história relativamente recente firmando-se no início deste século, sobretudo a partir da década de $20 \mathrm{com}$ o estabelecimento de imigrantes dinamarqueses e holandeses em Minas Gerais. Desde aquela época desenvolveu-se do ponto de vista industrial atingindo grandes volumes de produção. Inserido neste contexto, o queijo tipo Minas Frescal, ocupa uma posição de grande popularidade frente ao nosso mercado consumidor.

Principalmente agora, com a queda das fronteiras alfandegárias, com a implantação do MERCOSUL e com a redução das alíquotas de importação da maioria dos gêneros alimentícios originários de outros países, nossa indústria deve mobilizar-se em direção a uma produção economicamente mais competitiva visando a obtenção de produtos de melhor qualidade. Nesta busca, torna-se imprescindível a adoção de novas tecnologias de fabricação, para uma melhor adequação e competitividade da nossa produção industrial.

O queijo Minas Frescal, devido ao seu alto teor de umidade, é um produto bastante perecível, com durabilidade média de \pm 10 dias, dependendo do processo de fabricação. Sendo este um dos pontos críticos da qualidade deste queijo, afeta não só seu rendimento como também sua durabilidade. 
Há uma predominância atual do queijo Minas Frescal ser comercializado em embalagens plásticas comuns, amarradas ou fechadas com fechos metálicos, porém sem o emprego de vácuo. No interior destas embalagens forma-se geralmente um depósito de soro exsudado dos queijos que ocorre principalmente devido ao alto teor de umidade presente e, além de depreciar o produto, pode favorecer o desenvolvimento de microrganismos contaminantes causando frequentemente odores e sabores desagradáveis. Por estas razões o queijo Minas Frescal apresenta geralmente uma vida de prateleira muito curta mesmo sob condições adequadas de refrigeração, ou seja, sob temperaturas de 0 a $5^{\circ} \mathrm{C}$ (OLIVEIRA, 1986).

As carragenas, hidrocolóides extraídos das algas marinhas, têm uso generalizado na indústria de produtos alimentícios como um todo, especialmente na de produtos lácteos, face as suas propriedades geleificantes, espessantes e estabilizantes. Estas propriedades podem ser obtidas por meio do uso de baixas concentrações do produto comercial, não alterando os padrões de qualidade do produto em que é utilizado e onerando o custo final de maneira insignificante.

Segundo GARCIA (1995), a carragena constitui um dos melhores hidrocolóides para a aplicação em produtos lácteos devido ao seu sinergismo com a k-caseína e a sua habilidade de formar gel a baixas dosagens ou estabilizar bebidas lácteas a concentrações ainda menores. A carragena vem sendo aplicada em derivados do leite nos seguintes produtos: bebidas lácteas (estabilizantes /espessantes); em sobremesas prontas para consumo (espessante/ gelificantes); creme de leite culinário e para bater (estabilizante/espessante); pudins e flans em pó (estabilizantes/ gelificantes); em achocolatados UHT ou pasteurizados e em pó, como estabilizante das partículas de cacau e espessante.

Pela sua reatividade específica com as proteinas do leite e sua capacidade de reter umidade, pode reduzir a sinérese, melhorar a textura e 
aumentar a firmeza dos produtos lácteos. Trabalhos recentes desenvolvidos principalmente no exterior, mostraram que o uso de carragenas na produção de queijos pode também aumentar seu rendimento e a sua durabilidade no mercado. Assim sendo, supõe-se que sua utilização na fabricação do queijo tipo Minas Frescal possa contornar os problemas relativos à dessoragem, melhorar a aparência e reduzir as perdas do produto.

Este trabalho teve como objetivos estudar os efeitos da adição das carragenas na dessoragem do queijo Minas Tipo Frescal, no seu rendimento e sua influência na aceitabilidade sensorial por parte do consumidor. 


\section{REVISÃO DE LITERATURA}

\subsection{Queijo Tipo Minas Frescal}

O queijo é um alimento palatável e nutritivo que consiste basicamente de caseína e quase toda a gordura, sais insolúveis e material coloidal, junto com parte da umidade do leite, onde estão contidos lactose, proteínas do soro, sais solúveis, vitaminas e outros componentes menores. Nele, os sólidos totais do leite são concentrados pela ação do coalho, pelos agentes específicos da fermentação e por meios mecânicos. Transforma-se em um alimento menos perecível, variando de acordo com o tipo e composição do leite utilizado, substâncias adicionadas, processos de fabricação e condições de cura (WONG, 1974).

Dos produtos lácteos fabricados no Brasil, o queijo tipo Minas Frescal é um dos mais difundidos, de grande popularidade e consumido em praticamente todo o país. Embora muito semelhante ao "Queso Blanco" fabricado em outros países da América Latina, pode ser considerado um tipo de queijo desenvolvido no Brasil, e que teve a sua origem nas fabricações caseiras difundidas no Estado de Minas Gerais, as quais existem até hoje. Por volta de 1930 o referido queijo teve a sua definição tecnológica e desde então tem crescido o volume da sua fabricação industrial (OLIVEIRA, 1986).

Segundo FURTADO (1990), a produção de queijos no Brasil em 1987 foi de 240.798 toneladas, sem incluir o requeijão e, de acordo com o boletim da 
FAO (1995), em 1994 o Brasil produziu 330.000 toneladas de queijos de todos os tipos. O queijo Minas ocupa o $3^{\circ}$ lugar na produção nacional de queijos com uma produção de 27.628 toneladas, incluindo as variedades Frescal e Padronizado, atrás do Prato com 57.758 toneladas e do Mozarela com 47.326 toneladas (FURTADO, 1990). A produção do queijo Minas Frescal sofreu uma reversão de tendências a partir de 1980, quando então o Minas Padronizado era fabricado em quantidades duas vezes superior ao Minas Frescal. Em 1987, a produção do Minas Frescal foi de 26.609 toneladas, enquanto a do Minas Padronizado foi de 1.010 toneladas apenas. Esta tendência tem sido explicada pela preferência das empresas em produzir o Minas Frescal, um queijo de maior rendimento (6,0-6,5 litros de leite $/ \mathrm{kg}$, em média) que não requer maiores investimentos em estocagem e conservação, necessitando de menor capital de giro e permitindo a colocação do queijo no mercado a preços mais acessíveis a uma maior faixa da população, o que tem explicado a sua alta demanda nos últimos anos. Este tipo de queijo é produzido por um grande número de usinas em quase todo o país, especialmente nos estados de Minas Gerais e São Paulo, onde concentram-se as maiores produções de leite (FURTADO, 1990).

Como mostram os dados estatísticos (FURTADO, 1990), a indústria de queijos no Brasil está em expansão e, para que este empreendimento torne-se cada vez mais lucrativo, é preciso aumentar a produtividade das operações e diminuir as perdas causadas por problemas na fabricação e defeitos dos queijos.

Mantendo-se a mesma tecnologia e alterando-se o tempo e as condições de cura, têm surgido variações nos queijos tipo Minas, desde bastante úmido e sem nenhuma cura, como o Minas Frescal, até o Minas Curado, de sabor relativamente forte e consistência bastante dura ao ponto de poder ser usado para ralar. Tanto uma variação quanto a outra não tem ainda definição tecnológica como a existente para o Minas Meia Cura, observando-se desta forma uma grande variação nas características dos queijos comercializados como Minas Frescal, o 
qual tem se tornado cada vez mais importante economicamente (OLIVEIRA, 1986).

Com a evolução das técnicas industriais, a tecnologia de fabricação sofreu modificações visando ora a melhoria da qualidade do produto, ora um aumento no rendimento de fabricação. Nesta evolução constante surgiram modificações diversas, entre elas a fabricação com leite pasteurizado, o uso de cloreto de cálcio e o emprego de fermentos láticos (FURTADO et al, 1980a). Devido à adoção de diferentes métodos de fabricação, como por exemplo, a adição de ácido lático, o emprego de culturas láticas, o emprego da prensagem e variações na temperatura de coagulação, tornou-se um queijo bastante irregular em termos de padrão de consistência, textura, sabor, durabilidade e rendimento; chegando inclusive a ser fabricado pela técnica da ultrafiltração. Apresenta geralmente coloração interna esbranquiçada, consistência mole, textura fechada com algumas olhaduras irregulares e sabor variando do levemente ácido a suave, peso entre 0,5 a $3,0 \mathrm{~kg}$, sendo geralmente comercializado com menor peso (FURTADO \& LOURENÇO NETTO, 1994).

Segundo SAITO \& SCHIFTAN (1978), o queijo Minas frescal, por definição das Normas Técnicas Especiais Relativas a Alimentos e Bebidas (Decreto Estadual número 52.504 de 28 de julho de 1970), é o produto obtido de leite pasteurizado integral ou parcialmente desnatado, comprimido, levemente prensado ou não, exposto à secagem por 2 a 3 dias e consumido imediatamente. Deve apresentar, de preferência, formato cilíndrico baixo, de 4 a $7 \mathrm{~cm}$ de altura, tamanho médio, com peso variando de 0,5 a $1,5 \mathrm{~kg}$ aproximadamente, com bordos retos e faces planas, formando ângulos vivos. A crosta deverá ser mal formada, a consistência macia e de untura manteigosa, a textura deverá apresentar buracos mecânicos pequenos e pode apresentar ou não olhaduras em forma de cabeça de alfinete. Suas características sensoriais são aspecto de massa mole, coloração branco-creme homogênea, cheiro e sabor próprios, suave e levemente ácido. 
Como características físico-químicas, deve apresentar um máximo de umidade de $57 \% \mathrm{p} / \mathrm{p}$ e um mínimo de gordura de $40 \% \mathrm{p} / \mathrm{p}$ (em base seca). De acordo com FURTADO \& LOURENÇO-NETO (1994), sua composição média esperada é de 55 a $58 \%$ de umidade, 17 a $19 \%$ de gordura, 1,4 a $1,6 \%$ de sal e pH de 5,0 a 5,3.

Este queijo apresenta vários pontos críticos, durante a fabricação, que podem conduzir a alterações no produto final. Pode apresentar-se tanto com acidez excessiva como insuficiente, com reflexos no desenvolvimento de contaminações. Estas alterações influenciam a umidade final, o sabor do queijo, o rendimento e a durabilidade, afetando diretamente as características sensoriais e, consequentemente, a aceitabilidade pelo consumidor e comercialização (FURTADO \& LOURENÇO-NETO, 1994).

A manutenção das características sensoriais de um alimento é fundamental, uma vez que determina a sua atratividade pelo consumidor. A aparência do queijo, a consistência e o "flavor" estimulam os sentidos e provocam vários graus de reações de desejo ou rejeição e então, por um processo complexo, o consumidor escolhe um alimento pela qualidade sensorial. Além disto, uma correta avaliação da sua qualidade sensorial é essencial para fixar as bases de mercado e adaptá-las ao desejo do consumidor (VASSAL, 1987).

\subsection{Controle da Umidade na Fabricação de Queijos}

Segundo WEBER (1986), sinérese é a exsudação de água e de constituíntes solúveis do coágulo. É um fenômeno complexo e do ponto de vista físico é a eliminação do soro acompanhada por contração e enrijecimento do gel. Além da perda de água, perde-se a maioria dos componentes solúveis do leite como sais inorgânicos, lactose, proteínas do soro, nitrogênio não protéico e peptídeos liberados das micelas de caseína pelo coalho (NOËL et al, 1986). Na 
fabricação de queijos a saída de umidade do coágulo depende, entre outros fatores, do desenvolvimento de acidez nos diferentes estágios do processo (WHITEHEAD, 1948).

Durante a fabricação ocorrem variações no $\mathrm{pH}$, na temperatura, na pressão sobre os grãos, etc. Os fatores estão inter-relacionados e a temperatura altera a acidificação, que é alterada pelo teor de oxigênio presente, que é alterada pela mexedura e por fim altera a sinérese (WALSTRA et al, 1985).

O teor de umidade de um queijo, além de contribuir para o seu tipo, como os de massa mole, semi-mole ou dura, é de grande importância na determinação das suas características físico-químicas e da sua microbiota. $\mathrm{O}$ teor de umidade final é alcançado em função da remoção da umidade da coalhada durante o processo de fabricação, começando com a coagulação do leite pelo coalho e resultando na formação de um gel cuja contração ou sinérese permite a expulsão da umidade na forma de soro. Ao longo do processo de obtenção dos queijos, a coalhada é trabalhada ininterruptamente e os fatores que determinam a intensidade da remoção de umidade são: a firmeza da coalhada, o tempo de trabalho, a temperatura, o tamanho dos grãos, o teor de acidez, a velocidade e a frequência de agitação e $\mathrm{o}$ teor de sal adicionado (FURTADO \& WOLFSCHOON-POMBO, 1983).

A remoção da umidade da coalhada não é a única função da dessoragem, pois além deste fenômeno ocorre concomitantemente a desmineralização e a remoção da lactose. A desmineralização acontece em função do aumento progressivo da solubilidade do cálcio associado à caseína no estado coloidal, o qual migra para o soro. Esta solubilização ocorre pela a redução do $\mathrm{pH}$, alcançada pela fermentação da lactose a ácido lático, que por fim contribui para aumentar a porosidade do grão e regular a quantidade de cálcio que continua ligado à caseína, determinando muitas das propriedades fisicas do coágulo e com importante função na maturação de certos queijos. Já a quantidade de lactose que fica retida 
no coágulo, irá determinar a sua acidez, regular a sua desmineralização, afetando diretamente a maturação do queijo. Logo, a fermentação da lactose, a remoção de cálcio do coágulo e a dessoragem são fatores dependentes entre sí e fundamentais na determinação das características do coágulo (WEBER, 1986).

\subsubsection{Fase Líquida do Coágulo}

A fase líquida do gel caseínico existe sob três formas: a água de hidratação, ligada à proteína, de difícil remoção e também chamada de água ligada; a água livre, encerrada nos espaços intersticiais ou cavidades que envolvem os agregados micelares, é mais rapidamente expulsa na dessoragem e, caso fiquem retidos resíduos desta, podem originar defeitos na estrutura do queijo; e a água capilar, ocluída no interior da rede filamentosa do polímero caseínico em uma estrutura capilar, a qual é retida e não eliminada por contração ou aquecimento do coágulo (WEBER, 1986). É esta água capilar que vai determinar o teor de umidade do queijo e também o seu rendimento, formando um reservatório para a maturação. $\mathrm{O}$ seu volume varia com as técnicas de fabricação empregadas, ajudando a manter apropriado o conteúdo de umidade de cada queijo (FURTADO \& WOLFSCHOON-POMBO, 1983). A perda de soro não é acompanhada por mudança na hidratação das caseínas, mas por uma expulsão ativa, presumivelmente por agregação contínua que conduz à contração (GREEN \& GRADISON, 1987).

\subsubsection{Mecanismo da Dessoragem}

A dessoragem ocorre em dois estágios: o primeiro, no qual a maior parte do soro é perdida, vai desde o corte do coágulo até o final da prensagem e, o segundo, indo desde a prensagem até o final da maturação (WEBER, 1986). Na 
prática o início da dessoragem pode ser verificado quando ocorre o aparecimento de soro na superficie da coalhada, porém este é somente a manifestação visível do processo de separação que tem início no curso da coagulação e que prossegue em vários estágios da fabricação dos queijos. A formação do coágulo e a sinérese são dois aspectos de um mesmo processo básico e contínuo de agregação (GREEN \& GRADISON, 1987).

As primeiras ligações formadas após a coagulação são as com o hidrogênio e, apesar de serem numerosas, são fracas e têm pouca importância na dessoragem. Os rearranjos moleculares que ocorrem após a coagulação expôem grupos ativos entre os quais outras ligações são estabelecidas, particularmente por meio da ação de íons divalentes, principalmente o cálcio. Em seguida, com o avanço da sinérese, ocorre o estabelecimento de ligações do tipo pontes dissulfeto entre as moléculas de proteína, onde todos os aminoácidos sulfurados remanescentes na paracaseína são capazes de formar estas pontes, estágio este que pode ser considerado como o final da sinérese (WEBER, 1986). Este crescimento progressivo do número e da força das ligações conduz à contração da rede filamentosa de caseína e a expulsão do soro intersticial. Além disto, é provável que a ação proteolítica da enzima coagulante libere sítios de reação favoráveis ao aparecimento de novas ligações, uma vez que a tendência da dessoragem varia com a intensidade e especificidade da ação proteolítica da enzima utilizada (WEBER, 1986).

\subsection{Processo da Coagulação}

As micelas de caseína, agregados esféricos de submicelas e compostos de diferentes tipos de caseínas, fosfato de cálcio coloidal e água intersticial, possuem no seu exterior uma maioria de $\kappa$-caseína. Esta fração da caseína não é 
sensível à presença do cálcio e é altamente hidrofílica na sua parte $\mathrm{C}$ terminal, que situa-se no exterior da molécula como uma camada saliente. Esta camada protege as micelas e causa uma repulsão entre as mesmas impedindo a sua floculação. Quando submetida à ação do coalho ou enzima coagulante, a caseína é

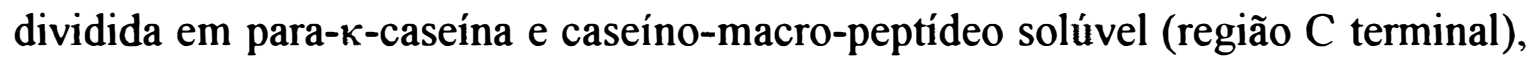
reduzindo muito as repulsões entre as micelas e expondo então as $\alpha$-e $\beta$-caseínas, suscetíveis a ação do cálcio. Com isto as micelas aproximam-se umas das outras e agregam-se, resultando na floculação e formando o gel. Inicialmente são formados agregados na forma de cordões que vão crescendo em tamanho até tocarem-se formando uma rede contínua de filamentos de micelas intercalados por outros cordões mais espessos, também chamados de nódulos. Estes nódulos irão compor as aberturas ou poros do gel que serão preenchidos pelo soro dentro da rede de proteínas do coágulo (WALSTRA et al, 1985). Com a saída deste soro ocorre uma redução da porosidade e fortalecimento das ligações químicas, contribuíndo para uma crescente coesão deste coágulo (LABLEÉ, 1986).

A dessoragem pode se manifestar de várias formas dependendo do tipo de coagulação a que é submetido o leite, se por coagulação enzimática ou por meio de ácidos (oriundos da fermentação ou adicionados) ou mista.

\subsubsection{Coágulação Enzimática}

No coágulo obtido exclusivamente por ação enzimática não ocorre a dessoragem espontânea. As micelas contraem-se mas a expulsão do soro é lenta e frágil, pois ele encontra dificuldades para fluir pela massa do coágulo que não foi desmineralizada, uma vez que não sofreu a ação da acidificação, e é pouco permeável. Para contornar este fenômeno é necessário multiplicar-se a superficie de exsudação cortando-se o coágulo (WEBER, 1986). 


\subsubsection{Coágulação Ácida}

Neste tipo de coagulação a estrutura micelar é destruída e o coágulo é formado de partículas de caseína pequenas e desmineralizadas, que não tem propriedades de dessoragem em função da sua excessiva desmineralização. Com a ausência do cálcio e formação de ligações fracas, do tipo eletrostáticas e hidrofóbicas, forma-se um coágulo gelatinoso que tende a fragmentar-se mais e contrair-se menos. A sua estrutura protéica é mais dispersa e difusa e menos interconectada do que o coágulo obtido por ação enzimática. Pela ausência da enzima coagulante e da sua ação proteolítica, a formação de novas ligações intermoleculares não é favorecida. A drenagem deste coágulo faz-se por um simples fluxo de líquido através da massa porosa, porém a retenção de umidade continua alta não somente pela ausência de forças contrativas mas também porque a caseína, sem o fosfato de cálcio micelar associado, forma uma massa plástica que mantém o soro retido no seu interior (WEBER, 1986).

Um coágulo obtido somente por acidificação mostrará pouca sinérese se não for cortado. No entanto, em leite desnatado coagulado por bactérias láticas a um pH na faixa de 3,8 a 4,5 , o seu corte conduz a uma drenagem de até $40 \%$ do seu volume inicial sendo expelido como soro. Em leite coagulado a um $\mathrm{pH}$ inferior a 5, a presença de renina aumentava consideravelmente a sinérese, tanto maior em função da sua concentração. Presumivelmente, isto mostra que existe uma mudança gradual do coágulo ácido para o obtido com renina (WALSTRA et al, 1985).

\subsubsection{Coágulação Mista}

$\mathrm{Na}$ maioria dos métodos de fabricação de queijos obtém-se o coágulo pela ação enzimática acompanhada da acidificação. Os microrganismos do 
fermento produzem o ácido lático pela fermentação da lactose, sendo que o desenvolvimento da acidez dependerá do tipo de queijo a ser obtido. O coágulo, por apresentar uma certa permeabilidade, alcançada com o desenvolvimento da acidez, pela progressiva solubilização dos sais de cálcio e pela pressão exercida pelas forças de contração do coágulo sobre o soro retido, tem uma tendência intrínseca à autodessoragem. Após algum tempo, que varia de acordo com as condições de fabricação, se o coágulo for deixado em estado de repouso, surgem gotículas sobre sua superfície que vão crescendo em tamanho e número até o envolver completamente (WEBER, 1986). Ocorre uma redução no volume total do coágulo enquanto a massa da rede protéica continua a mesma. Esta exsudação, ou fluxo de soro para fora do coágulo, é necessária para permitir uma união das partículas de paracaseína e produção de coesão, para que ocorra a contração (LABLEÉ, 1986).

Neste coágulo, a sinérese resulta da contínua interação entre as proteínas devido a formação de vários tipos de ligações que podem ocorrer após a redução da camada de água que envolve as micelas. Num primeiro estágio, pela ação da protease, inicia-se a desidratação da caseína liberando compostos hidrofilicos que envolvem as micelas e seus agregados e que preveniam a sua reunião e opunhamse à dessoragem. Nos estágios subsequentes vai ocorrendo uma progressiva redução da água de hidratação da rede protéica, permitindo o estabelecimento de vários tipos de ligações entre as micelas de caseína, cada vez mais fortes e mais numerosas, causando a contração do coágulo e expulsão do soro, que torna-se visível. Principalmente nos queijos duros e de massa cozida, o grau de hidratação das micelas é bastante reduzido, favorecendo o estabelecimento de ligações intermoleculares secundárias e a dessoragem (WEBER, 1986).

No gel obtido por renina pode-se observar uma alteração considerável com o tempo. Ao microscópio eletrônico verifica-se inicialmente as micelas individualizadas, que vão perdendo a sua identidade, fundindo-se em filamentos 
de paracaseinato. Inicialmente a área de contato entre duas micelas na rede protéica é pequena, porém com o rearranjamento das submicelas e do fosfato de cálcio, ele vai crescendo gradualmente (WALSTRA et al, 1985).

A matriz protéica observada microscopicamente é aberta, tendo cavidades de vários tamanhos. A rede de partículas é mineralizada e densa, porém com o decorrer da dessoragem ela se desmineraliza, as partículas do coágulo aproximam-se reduzindo a porosidade. Nestes poros situam-se os espaços que seriam preenchidos pelo soro, glóbulos de gordura e bactérias dentro da rede tridimensional de proteínas do coágulo, que esvaziam-se ficando menores e aproximando as partículas de paracaseína e também aumentando as características de coesividade do coágulo, não só pela compressão mas sobretudo pelas ligações formadas (LABLEÉ, 1986).

\subsection{Corte da Massa}

A divisão do coágulo em grãos aumenta a sua superficie de exposição permitindo uma rápida e melhor separação do soro. O corte deve ser feito sempre com muito cuidado, considerando-se a fragilidade do coágulo, que deve ser cortado no momento em que estiver no ponto. Neste momento ele divide-se de forma limpa, sem despedaçar-se, devendo ser movimentado lentamente para evitar a sua fragmentação, causa de redução do rendimento final do queijo. É apropriado realizar-se o corte enquanto o coágulo ainda estiver bastante mineralizado e antes de tornar-se excessivamente firme. Um corte feito muito cedo, com o coágulo sem a firmeza adequada, pode levar a altas perdas de gordura no soro, alto conteúdo de umidade no queijo e corpo fraco, com consequente perda no rendimento (WONG, 1974). 
Um corte em grãos pequenos favorece a dessoragem, mas a sua redução a tamanhos menores que $0,635 \mathrm{~cm}(1 / 4$ de polegada) pode elevar em muito as perdas de gordura. Também aumenta os "cheese dust", partículas ou fragmentos de coágulo de tamanho muito pequeno causadoras da redução do fluxo de soro por entre as partículas e para fora da massa do queijo. Com isto ocorre uma redução na velocidade e volume de dessoragem, com uma retenção anormal de soro (e de lactose) na massa, causando uma excessiva acidificação e defeitos subsequentes na maturação. Por estas razões é muito importante o corte dos grãos em tamanhos uniformes, uma vez que a não uniformidade leva a variações na firmeza, elasticidade e conteúdo de umidade, ocasionando defeitos de textura e de qualidade do produto final (WONG, 1974).

Um grão de coágulo reune três componentes principais: o soro, a matriz de paracaseinato (incluindo o fosfato de cálcio) e os glóbulos de gordura. Porém logo após o corte, com o início da dessoragem, inicia-se um processo de concentração da quantidade de paracaseína na camada externa do grão, que logo será maior do que no seu interior. Ocorre uma alteração da permeabilidade desta camada, também chamada de pele, que como um filme elástico, retém na porção interna do grão maior teor de gordura e umidade, tornando-o mais brando e macio do que externamente. Esta pele reduz a deformabilidade do grão retardando a sua contração (AKKERMAN et al, 1994). Esta camada externa do grão não contém mais glóbulos de gordura e com a subsequente agitação da coalhada perdem-se no soro. Estes glóbulos impedem físicamente a formação de ligações entre a superficie dos grãos e na sua ausência, os grãos unem-se fortemente sendo a fusão determinada pelo tamanho da área de contato entre os mesmos (AKKERMAN et al, 1993).

Após o corte do coágulo os grãos devem ser deixados em repouso no tanque de fabricação por alguns minutos, permitindo que ocorra a exsudação do soro e um ligeiro aumento na sua firmeza. Esta fragilidade interna do grão exige 
que inicialmente a agitação seja lenta para que as perdas de componentes do coágulo para o soro não sejam muito grandes, especialmente de gordura. Neste momento não devem existir grumos ou blocos coesos de grãos, pois estes iriam reter grande quantidade de umidade, podendo originar defeitos nos queijos. Nas etapas subsequentes da fabricação de queijos e com o progresso da fermentação, o grão vai adquirindo uma maior firmeza e contraindo-se conforme vai perdendo o soro que retinha no seu interior, tornando-se mais denso e mais coeso (WONG, 1974).

Com a drenagem ocorrem quatro grandes modificações com os grãos que são simultâneas e inter-relacionadas: a expulsão do soro adicional, a deformação, a fusão, e o fluxo de soro através das suas aberturas. A função da fusão dos grãos na dessoragem é a compactação de uma camada de grãos e a sua modificação, ou evolução do arranjamento inicial, alterando o tamanho e o número de aberturas ou poros entre eles. É essencial para a fabricação de queijos transformando os grãos individuais em uma massa coesa resultante de dois processos: do fluxo de partículas no coágulo, aumentando a sua área de contato, e da formação de ligações entre a rede de partículas do coágulo, semelhante àquela que ocorre no interior do grão (AKKERMAN et al, 1993; AKKERMAN et al, 1994).

\subsection{Sinérese da Coalhada}

A sinérese pode ter como causa um rearranjo da rede de partículas de paracaseína, as quais têm um número limitado de ligações químicas entre sí. Espalhados por toda a superfície de reação existem numerosos sítios ativos, no entanto, na rede formada a maior parte da superfície de uma partícula não pode 
tocar outra partícula e participar da formação de novas ligações (WALSTRA et al, 1985).

O rearranjo de partículas numa rede mais compacta aumentaria o número de ligações, mas estas não podem alcançar facilmente uma configuração mais compacta porque estão praticamente imobilizadas na matriz do gel. A rede deve ser deformada localmente para formar novas ligações ou aumentar o seu número. Alguns mecanismos hipotéticos são sugeridos para explicar a formação das novas ligações: forças atrativas de longo alcance entre as partículas, fluxo micelar que aumenta a área de contato entre as micelas, movimento térmico dos filamentos e quebra espontânea dos filamentos ou induzida por forças externas (WALSTRA et al, 1985).

Uma outra possível causa da sinérese seria a contração das partículas de caseína. Se os blocos constituintes de uma rede se contraem, toda ela irá contrairse proporcionalmente. Porém, se as condições continuarem inalteradas após a floculação, é improvável que ocorra a contração das micelas de caseína. As mudanças nas micelas que causam a floculação, isto é, a acidificação e a adição de renina, podem também induzir à contração das micelas, mas devido à pequena dimensão das micelas, a contração seria tão rápida que estaria praticamente terminada antes que a rede tivesse sido formada. A mudança de condições após a formação do gel pode causar a contração das partículas de caseína. Uma redução no $\mathrm{pH}$ e um aumento na temperatura podem aumentar consideravelmente a sinérese, e isto pode ser, ao menos em parte devido à contração das partículas (WALSTRA et al, 1985).

A sinérese pode ser facilmente estimada pelo teor de umidade do queijo ou pelo soro que é exsudado do gel. Vários métodos são utilizados para estimá-la e baseiam-se na medida do encolhimento do coágulo, da quantidade de soro perdido por ele, da sua matéria seca e da sua densidade (WALSTRA et al, 1985). 
Segundo WEBER (1986), os fatores que alteram a sinérese podem ser separados em: relacionados ao leite, indiretos e diretos.

Nos fatores relacionados ao leite, algumas das variáveis estudadas foram: a espécie dos animais, com os caprinos exibindo maior sinérese que os bovinos; a raça, com a raça Jersey apresentando sinérese mais rápida do que as outras, apesar de ter um leite com teor de proteína e gordura mais elevado; o animal individual dando diferenças consideráveis; o estágio de lactação e de alimentação, exercendo pouca influência; e a mastite, quando severa, reduzindo a capacidade de coagulação deste leite e a sinérese do coágulo.

$\mathrm{Na}$ composição de diferentes amostras de leite existem alterações naturais ou induzidas nos seus principais componentes como a gordura, as proteínas ou a água. WHITEHEAD (1948), em seus experimentos, investigou as diferenças causadas pela diferente composição do leite nas características de retenção de umidade no coágulo. As variações no conteúdo de gordura e caseína do leite de diferentes raças de vacas indicaram que a gordura ajuda a reter mais umidade no coágulo e quanto maior o seu teor, mais drástico será o tratamento necessário para reduzir o conteúdo de umidade final para os níveis desejados no queijo. Os coágulos obtidos de leite com menor teor de caseína (gado Holandês), retêm umidade durante o processo de fabricação de queijos com mais coesividade do que os de maior teor (gado Jersey). Segundo WALSTRA et al (1985), o aumento do teor de proteínas reduz a sinérese e o aumento do teor de gordura reduz a sua velocidade. Com a alteração da concentração de gordura do leite de $2 \%$ para $6 \%$, a sua sinérese é reduzida em $85 \%$.

Coágulo obtido com teor de gordura normal dessora melhor do que aquele a partir de leite desnatado. A gordura, apesar de não participar da formação do coágulo, é ocluída no seu interior. Neste caso, na formação de coágulo com leite desnatado, as partículas do próprio coágulo preenchem as cavidades intergranulares, reduzindo a sua permeabilidade. A homogeinização do 
leite reduz significativamente a sinérese em função da incorporação das micelas de caseína à superfície dos glóbulos de gordura, que passam então a fazer parte da rede de paracaseína (WALSTRA et al, 1985).

$\mathrm{O}$ aquecimento do leite a uma temperatura que desnature as proteínas do soro diminui a sinérese do coágulo obtido por enzimas. A redução da sinérese está quase que linearmente correlacionada com a desnaturação da $\beta$-lactoglobulina. $O$ mesmo aquecimento realizado em leite sintético, não contendo as proteínas do soro, dificilmente afeta a sinérese. A adição de $\kappa$-caseína ao leite reduz o efeito prejudicial do aquecimento, provavelmente porque a $\beta$-lactoglobulina, que supostamente reage com a $\kappa$-caseína durante o aquecimento, não afeta as micelas de caseína. Provavelmente o aumento na quantidade de proteínas do soro associadas à caseína causaria um aumento no volume da rede protéica diminuíndo a possibilidade de sinérese (WALSTRA et al, 1985).

Sendo alto o teor de proteínas do leite, o efeito é desfavorável na dessoragem. Pela presença de maior teor de caseína, a drenagem é um pouco reduzida, enquanto pela presença de proteínas do soro desnaturadas pelo tratamento térmico, a drenagem é reduzida consideravelmente.

$\mathrm{Na}$ fabricação de queijos, o cloreto de cálcio é usualmente adicionado para repor o cálcio insolubilizado durante o tratamento térmico do leite, melhorando a coagulação. WALSTRA et al (1985) em seus estudos de revisão, relataram que pequenas adições (até $10 \mathrm{mmol}$ ) aumentaram ligeiramente a sinérese. A atividade do íon cálcio deve estar num certo nível para alcancar a sinérese e o fosfato de cálcio coloidal tende a reduzir a sinérese.

$\mathrm{O}$ aumento da força iônica do leite com íons monovalentes $(\mathrm{NaCl})$, inicialmente não causou mudanças na sinérese. Grandes aumentos na força iônica causam uma redução na sinérese mas o leite que foi adicionado de sais dificilmente coagulará pela ação da renina (WALSTRA et al, 1985). 
Os fatores indiretos, ou responsáveis pela fornnação do coágulo, englobam o desenvolvimento da acidez e o uso de enzimas coagulantes. A acidificação causa a redução da água de hidratação da micela de caseína e a solubilização parcial dos sais de cálcio, expondo certos sítios da reação favorecendo a formação das ligações necessárias à contração do coágulo e assegurando a sua permeabilidade pela eliminação de um certo número de ligações com o cálcio. A drenagem ocorre de forma lenta até pH 5,5 e é acelerada quando o pH atinge 4,9. Entre 4,9 e 4,7 a drenagem espontânea é máxima e depois vai reduzindo até o desaparecimento do arranjamento micelar. $\mathrm{O}$ aumento progressivo da solubilidade dos sais de cálcio da micela é acompanhado por uma mudança nas propriedades estruturais do coágulo, tornando mais difícil a drenagem por meios mecânicos. Se o leite foi acidificado a um $\mathrm{pH}$ menor antes da adição da renina, a sinérese é mais rápida. Se o $\mathrm{pH}$ é reduzido durante a sinérese, ela é ainda mais elevada do que se este $\mathrm{pH}$ fosse alcançado anteriormente, isto ocorre porque os blocos que constituem a rede de proteínas do coágulo tendem a contrair-se devido a mudança do pH (WALSTRA et al, 1985).

$\mathrm{O}$ uso de maiores quantidades de enzimas coagulantes conduz à formação do coágulo mais rapidamente e com suas ligações sendo formadas mais cedo, levando a um rápido aumento na rigidez deste coágulo, tornando-se mais impermeável com maior rapidez. O desenvolvimento da firmeza do coágulo e a dessoragem, variam com o teor de enzima coagulante até que seja atingido um limite entre enzima e substrato. A tendência de início da sinérese parece estar relacionada à atividade proteolítica total presente no gel. Segundo WALSTRA et al (1985), a concentração de renina não altera a sinérese, variando apenas a firmeza do coágulo no momento do corte. Um corte tardio resultará na redução da sinérese do coágulo e quanto maior o tempo de corte, menor será a dessoragem.

A temperatura a que o leite foi submetido antes da coagulação, afeta grandemente a sinérese do coágulo enzimático e todos os resultados mostram que 
ela reduz-se com o aumento da temperatura. A manutenção do leite por algum tempo a baixa temperatura não tem efeito sobre a sinérese e provavelmente, quaisquer efeitos prejudiciais do pré-resfriamento são desfeitos por um pré aquecimento adequado antes da coagulação, processo normalmente utilizado na fabricação de queijos para assegurar uma coagulação dentro dos padrões. Para o coágulo obtido por acidificação ainda não foram determinados os efeitos da temperatura sobre a sinérese (WALSTRA et al, 1985).

Os fatores diretos são aqueles responsáveis pelas alterações na dessoragem após a obtenção do coágulo. Se este for deixado em repouso após a sua obtenção e submetido somente a ação da enzima coagulante e do desenvolvimento de acidez, sua dessoragem será lenta, e para muitos tipos de queijos não consegue-se alcançar a composição adequada desta forma, por isto são introduzidos fatores como os tratamentos térmico e o mecânico.

Temperaturas altas aumentam a dessoragem por favorecer todos aqueles fenômenos que ocorrem após a coagulação, como a aceleração da formação das ligações químicas, formação de ácido e redução da viscosidade do coágulo. Um coágulo dessorado a $50^{\circ} \mathrm{C}$ alcança uma concentração de sólidos de $54 \%$, enquanto o dessorado a $32^{\circ} \mathrm{C}$ chega somente a $35 \%$, isto é, retém maior quantidade de soro. Para cada tipo de queijo é utilizada a temperatura necessária para alcançar-se a concentração de sólidos desejada. $\mathrm{O}$ desenvolvimento do $\mathrm{pH}$ do coágulo também é controlado pela temperatura, que influi na ação acidificante dos microrganismos do fermento. Em queijos frescos chega-se a $20 \%$ de sólidos a um pH de 4,4 , mas nos queijos duros, onde o tratamento térmico é mais severo, alcança-se $60 \%$ de sólidos e um pH de 5,2 (WEBER, 1986).

Quanto maior for a complexidade do tratamento mecânico dispensado ao coágulo (corte, mexedura, dessoragem e prensagem), menor será o seu conteúdo 
de umidade e maior o conteúdo de minerais deste coágulo (WALSTRA et al, 1985).

A mexedura ou agitação é operação necessária devido a propensão dos grãos de se repolimerizarem ou formarem blocos contínuos que provocariam a eliminação do soro lenta e incompleta. Ela aumenta consideravelmente a sinérese, não só por prevenir a sedimentação dos grãos em camadas, mas também por aplicar alguma pressão aos grãos em função do gradiente de velocidade no líquido e pela colisão dos grãos entre sí. Uma velocidade de agitação maior do que a necessária para impedir a sedimentação dos grãos poderia causar um significativo aumento na sinérese. A diluição do soro com a adição de água reduz a sinérese, possivelmente por reduzir a taxa de colisão entre os grãos ou por torná-las menos frequentes, enquanto a remoção de soro aumenta o efeito da mexedura. Se ela for muito vigorosa enquanto os grãos ain da contêm elevado teor de umidade, pode causar ruptura e aumento da perda de caseína, de gordura e de finos para o soro. $\mathrm{O}$ aumento da acidez reduz a tendência dos grãos de repolimerizarem-se e em coágulos obtidos por acidificação praticamente não é necessário a mexedura, mas nos obtidos por enzima, ela deve ser contínua (WALSTRA et al, 1985).

\subsection{Rendimento}

Entende-se por rendimento a quantidade de queijo obtida a partir de um determinado volume ou peso de leite. Não obstante, o rendimento também depende das normas legais que regulam a composição das diferentes variedades de queijos e no processo de fabricação deve-se obter um queijo cuja composição atenda as normas vigentes visando o melhor rendimento possivel (DUMAS et al, 1991). 
$\mathrm{O}$ rendimento é um dos parâmetros mais importantes que orientam o queijeiro na elaboração do queijo e de importância fundamental na determinação do custo do produto e na sua rentabilidade. Ele varia de acordo com a composição do queijo e especialmente com o seu teor de umidade, e por isto existem as diferenças entre os queijos duros, semi-duros ou moles, variando também de acordo com as técnicas de fabricação que são específicas e adequadas para cada tipo de queijo, de acordo com o trabalho RENDIMENTO... (1993), e os autores WALSTRA et al (1985) e WEBER (1986).

Segundo FURTADO \& LOURENÇO-NETO (1994), o rendimento médio que pode ser obtido na fabricação do queijo Minas Frescal situa-se entre 6,0 a 6,5 litros de leite/kg de queijo. O rendimento médio logo após a fabricação do queijo Minas Frescal está na faixa de 5,7 a 6,5 litros de leite/kg de queijo, de acordo com o trabalho RENDIMENTO... (1993).

Os componentes principais do extrato seco como a proteína, gordura e a umidade são os maiores responsáveis pelo rendimento dos queijos e também os de mais dificil controle. Aproximadamente $\mathbf{8 0} \%$ do volume inicial de leite é perdido na dessoragem (BULLENS et al, 1994).

Os principais pontos que podem afetar o rendimento de uma fabricação de queijo são: a composição do leite, as perdas durante o processamento e a determinação do ponto de massa pelo queijeiro. Anteriormente, acreditava-se que era o elevado teor de gordura do leite que garantia um alto rendimento, porém para os glóbulos de gordura serem retidos ou "aprisionados" na malha entrelaçada do coágulo é necessário que o leite tenha um teor mínimo de caseína e cálcio para a formação de uma malha protéica bem estruturada, uma vez que são estes seus principais componentes, de acordo com o trabalho RENDIMENTO... (1993).

$\mathrm{Na}$ fabricação de queijos não se obtém igual rendimento para todos os componentes do leite. Suas proporções e o valor exato de aproveitamento dependem principalmente do tipo de queijo elaborado e do tamanho dos grãos, 
entre outros fatores. Um aumento no teor de proteínas do leite (principalmente caseínas) implica num aumento da transição de todos os demais elementos do leite na coagulação. Variando-se somente o teor de proteínas do leite o rendimento é proporcional a esta variação, podendo perceber-se claramente o papel decisivo da caseína. Quando varia-se somente o teor de gordura, o rendimento varia no mesmo sentido, porém em menor proporção do que no caso das proteínas. Pode-se afirmar que o aumento do teor de gordura do leite aumenta o rendimento, porém é um fator interdependente com o teor de proteínas (FURTADO \& WOLFSCHOON-POMBO, 1979a).

As perdas de caseína e gordura no soro podem alcançar até $0,10 \%$ e $0,30 \%$, respectivamente. Algumas das diversas causas que podem conduzir a maiores perdas destes componentes para o soro são: a formação de agregados de glóbulos de gordura que migram para a superfície do leite deixando de fazer parte do coágulo, o corte excessivo, a agitação muito intensa da coalhada ainda branda, o aquecimento muito rápido (DUMAS et al, 1991), o coalho de baixa qualidade ou em dosagem errada, leite muito ácido, a não utilização de cloreto de cálcio, o leite mamítico, etc, de acordo com o trabalho RENDIMENTO...(1993).

Na maioria das fábricas de queijo, principalmente no Brasil, o ponto da massa é obtido com base na experiência do queijeiro e varia de acordo com o tipo de queijo e sua utilização (fatiamento ou "de mesa"). Este "ponto", além de influir na qualidade do queijo, também influi na quantidade de água que ficará retida no queijo, com reflexos no rendimento, de acordo com o trabalho RENDIMENTO... (1993). 


\subsection{As Carragenas}

As carragenas são componentes celulares de certas algas vermelhas pertencentes à classe Rhodophyaceae, as quais sintetizam heteropolissacarídeos complexos, sendo o principal deles as galactanas, que ocorrem tanto nas paredes celulares quanto na matriz intracelular e pode constituir de 10 a $70 \%$ do peso seco do corpo da planta (MORAIS et al, 1989). São polímeros solúveis em água que têm a propriedade de, mesmo quando utilizados em concentrações muito baixas, modificar o comportamento reológico do meio em que são adicionados e por isso encontram muitos usos na indústria da alimentação, farmacêutica e de cosméticos (MARTIN, 1984).

São colhidas anualmente mais de oitocentas mil toneladas de algas secas, utilizadas principalmente para fins alimentícios. Estas algas são classificadas em quatro categorias maiores, de acordo com a cor predominante do pigmento, podendo ser marrom, vermelho, azul e verde-azulado, mas somente as marrons e as vermelhas são fontes de hidrocolóides, sendo que as últimas contêm vários deles, como o ágar e a carragena, ambos polímeros da galactose (GLICKSMAN, 1983a).

Segundo o "Food Chemical Codex III", a carragena é definida como: "produto obtido por extração com água ou solução de álcali de certas espécies da classe Rhodophyaceae" (algas vermelhas). São hidrocolóides constituídos principalmente de copolímeros de ésteres sulfatos de galactose com potássio, sódio, magnésio e amônea, e 3,6-anidrogalactose (GLICKSMAN, 1983b).

A aplicação empírica destas algas na alimentação humana e na medicina remonta a muitos séculos. Entretanto, foi somente nos anos de 1930-1940 que as primeiras usinas de beneficiamento foram construídas na costa leste dos E.U.A. para o fornecimento comercial do extrato de algas purificado (LOCALLIER, 1977). Com o advento da II Grande Guerra Mundial, a carragena passou a ser 
produzida em quantidades apreciáveis como um substituto ao ágar japonês (LORENA \& FERREIRA, 1989).

As algas vermelhas convencionais usadas para a obtenção das carragenas são encontradas em várias partes do mundo e ocorrem principalmente na costa da Irlanda, Inglaterra, França, Espanha, Chile, Noruega, Ilhas das Filipinas e em grande profusão na costa da Ilha Halifax-Prince Edward (WHISTLER \& DANIEL, 1985), e em áreas não costeiras da Indonésia, Korea e México (GLICKSMAN, 1983a). No Brasil, embora ocorram outras espécies de algas conhecidas como fontes de carragenas, a única que ocorre abundantemente é a Hypnea muciformis, da família Hypneaceae, sendo que a maior concentração desta biomassa localiza-se principalmente na costa nordeste do país. Trabalhos de prospeç̧ão no litoral do Rio Grande do Norte, em uma faixa com profundidade variando de 0 a 30 metros, a partir das marés baixas, mostraram que os bancos mais ricos de algas de importância econômica estão localizados na parte mais rasa, dificilmente ultrapassando os dois metros de profundidade. Das espécies presentes destacam-se pela maior abundância a Hypnea muciformis e a Gracilaria verrucosa, ambas totalizando cerca de 3.100 toneladas em peso úmido (MORAIS et al, 1989).

As carragenas apresentam-se sob a forma de um pó insípido e inodoro, cuja cor varia do creme ao branco. São caracterizadas segundo suas propriedades físicas como força do gel e ação espessante. A mistura de carragenas com outras gomas origina produtos comerciais com especificações bem definidas (MORAIS et al, 1989).

Existe uma grande diversidade de usos das carragenas como aditivos alimentares devido aos vários modos de utilização dentro dos mais variados hábitos alimentares de cada país. A estimativa do mercado mundial das carragenas para utilização no domínio alimentar em 1982 pode ser observada na Tabela 1 (MARTIN, 1984). 
TABELA 1 - Mercado mundial das carragenas.

\begin{tabular}{ccccc}
\hline País & $\begin{array}{c}\text { Total de } \\
\text { carragenas } \\
\text { (tons) }\end{array}$ & $\begin{array}{c}\text { Consumo na } \\
\text { alimentação } \\
\text { (tons) }\end{array}$ & $\begin{array}{c}\text { População } \\
\text { (milhões) }\end{array}$ & $\begin{array}{c}\text { Consumo } \\
\text { pessoa/ano } \\
(\mathbf{g})\end{array}$ \\
\hline E.U.A & 3.200 & 2.700 & 240 & 11 \\
\hline Inglaterra & 1.700 & 600 & 55 & 11 \\
\hline Japão & 1.700 & 1.400 & 110 & 13 \\
\hline Alemanha & 1.700 & 1.100 & 60 & 18 \\
\hline França & 1.500 & 1.000 & 55 & 18 \\
\hline Outros & 4.200 & 2.800 & & \\
\hline Total & 14.000 & 9.600 & & \\
\hline
\end{tabular}

\subsubsection{Estrutura Molecular das Carragenas}

O termo carragena abrange uma família de polissacarídeos lineares sulfatados de D-galactose e 3,6-anidro-D-galactose que são extraídos de várias algas vermelhas. De início foi obtida comercialmente da alga Chondrus crispus, encontrada ao longo da costa nordeste dos E. U. A. e Canadá em mais ou menos 1937 e referida como extrato de Musgo Irlandês.

Em 1953, identificou-se o extrato original de carragena da alga Chondrus crispus, obtido por precipitação com cloreto de potássio, consistindo de duas frações, uma geleificante chamada de kappa carragena e uma não geleificante chamada de lambda carragena (GLICKSMAN, 1983b). Adicionalmente foi identificada e caracterizada no extrato da alga Euchema 
spinosum um terceiro tipo de carragena geleificante, a iota carragena, e posteriormente foram identificadas quatro outras frações menos importantes.

As frações kappa, lambda e iota são as de maior ocorrência natural nas carragenas obtidas das algas vermelhas e apenas estas são disponíveis no comercio; a estrutura básica destas frações podem ser observadas na Figura 1. A composição depende do tipo de alga utilizada no processo de extração bem como da sua ocorrência geográfica. O conhecimento das frações aproximadas das diferentes algas utilizadas possibilita antever as propriedades dos extratos. Além disto, pode produzir-se extratos comerciais que correspondam exatamente às características geleificantes e espessantes exigidas pelas utilizações, aplicando-se condições apropriadas de processamento e combinando diferentes espécies de algas. A utilidade e importância dos hidrocolóides é baseada nas suas propriedades funcionais (MORAIS et al, 1989).

Os hidrocolóides, também conhecidos como gomas, são polímeros de cadeia longa que ao serem dissolvidos ou dispersos em água geram um efeito espessante ou produtor de viscosidade. $\mathrm{O}$ espessamento em água é comum à maioria das gomas, variando entre elas e sendo esta a razão básica do seu uso.

Enquanto todas as gomas são espessantes e produzem viscosidade, somente algumas formam géis. As propriedades geleificantes, variáveis em textura e características próprias do gel, são usadas em produtos alimentares.

As propriedades físicas de um polissacarídeo são determinadas pela composição, pela estrutura espacial das suas unidades básicas e pelo peso molecular, que varia entre 100.000 a 1.000 .000 (MORAIS et al, 1989). 

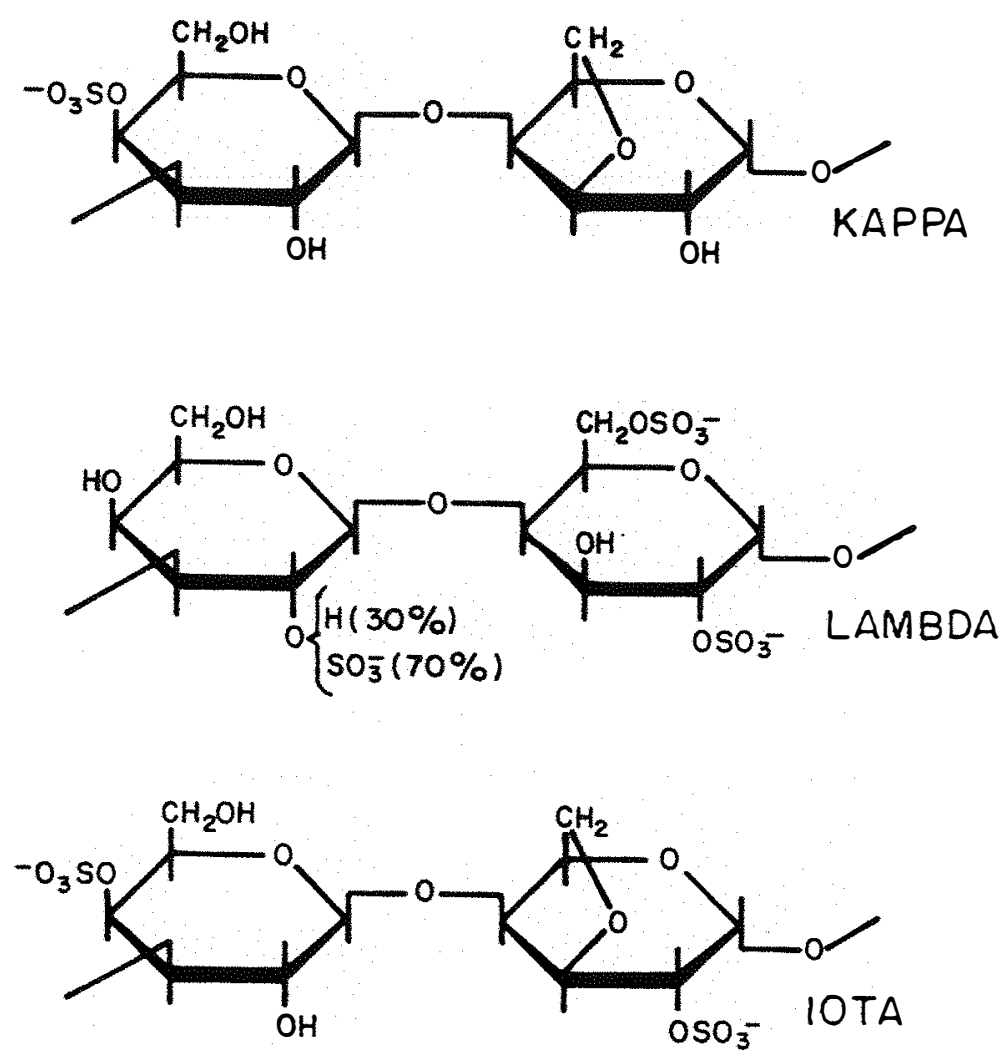

FIGURA 1- Estrutura básica de unidades de repetição das carragenas (GLICKSMAN, 1983b). 
Os efeitos físicos devem-se à interação das moléculas do polissacarídeo consigo mesmas e com as do ambiente em que estão presentes, como as de proteínas, que provém a suspensão e estabilidade da solução, e as de lipídios, que provém efeitos viscosos ou de emulsificação. $\mathrm{Na}$ maioria dos seus usos os polissacarídeos existem em um ambiente rico em moléculas de água e mesmo tendo que interagir apropriadamente e de forma benéfica com as moléculas de proteínas, de lipídios e outras do ambiente comumente encontrado nos alimentos, eles devem reagir inicial e continuamente com as de água. Nestas interações os polissacarídeos cumprem suas funções usuais, que são principalmente aquelas de prover viscosidade, estabilidade das soluções, capacidade de formar suspensões, ação emulsificante e geleificante. Além de combinar estas propriedades o polímero precisa ser compatível com os outros polissacarídeos, proteínas e a miscelânea de materiais biológicos presentes nos alimentos (GLICKSMAN, 1982).

\subsubsection{Solubilidade}

No estado sólido todos os polissacarídeos possuem regiões onde as moléculas, ou as suas cadeias, estão arranjadas de uma forma desorganizada. Estas regiões amorfas possuem inúmeras ligações de hidrogênio que podem ser facilmente hidratadas. Os polissacarídeos completamente secos têm pequena, porém forte, afinidade pela água e em condições normais de umidade contém de 8 a $10 \%$ de água de hidratação ocupando as ligações hidrogênio e não envolvidas em ligações intermoleculares. Quando um polissacarídeo solúvel é colocado em água, as abundantes moléculas de água penetram rapidamente nas suas regiões amorfas, ligando-se aos sítios disponíveis do polímero, competindo por eles e reduzindo a números bem pequenos outras pontes interpolissacarídicas ainda existentes. Os segmentos de uma cadeia de polissacarídeos tornam-se 
completamente solvatados afastando-se por movimento cinético, rompendo outras ligações interpolissacarídicas, que são completamente solvatadas e solubilizadas. Um menor número de segmentos estão ainda conectados a outras cadeias de polissacarídeos, que ainda não estão completamente solvatadas, formando um estado intermediário na dissolução da molécula do polímero e representando um estágio de transição do gel.

Os polissacarídeos solúveis continuam a hidratar-se até que as suas moléculas tornem-se completamente envolvidas pelas de água e parcialmente imobilizadas. Muitos polissacarídeos não hidratam-se além do estágio intermediário de gel e as suas moléculas permanecem incompletamente dispersas, formando géis com propriedades fisicas dependentes da extensão da hidratação ou das ligações interpolissacarídicas remanescentes (GLICKSMAN, 1982).

Todas as frações das carragenas são solúveis em água e insolúveis em solventes orgânicos, óleos e gorduras. Em água formam soluções viscosas ou géis dependendo da proporção das frações das carragenas e do equilíbrio de cátions da solução. A lambda carragena dissolve-se facilmente em água fria independente dos cátions presentes, porém para dispersão da kappa carragena devem ser aplicados o calor e sais de potássio.

A solubilidade das carragenas em água depende essencialmente dos teores de grupos sulfatados (muito hidrófilos), dos cátions a eles associados e da presença de resíduos de 3,6-anidro-galactose (hidrófobos) (MORAIS et al, 1989). As fortes cargas repulsivas dos grupos sulfato favorecem a separação das cadeias das macromoléculas e, como consequência, a solubilização pode ser feita a temperatura ambiente qualquer que seja o cátion associado aos sulfatos. A lambda carragena contém uma grande proporção de grupos sulfatados e nenhum resíduo de 3,6-anidro-galactose, enquanto a kappa carragena contém menor proporção de grupos sulfatados, o que a torna menos hidrofilica. A solubilização total não poderá ser assegurada a não ser pela elevação da temperatura, que dependerá 
também do cátion associado (MARTIN, 1984). A fração kappa é solúvel apenas em água fria quando na forma de sais de sódio. Outros cátions, como o potássio e o cálcio, permitem que somente as partículas de hidrocolóides intumesçam a frio e um aquecimento até $60^{\circ} \mathrm{C}$ é necessário para conseguir sua completa solubilização. A iota-carragena possui estrutura molecular e propriedades intermediárias entre a kappa e a lambda carragenas.

Devido a natureza altamente hidrofilica de todas as frações das carragenas, certas precauções deverão ser tomadas para a dispersão correta em água ou leite evitando-se a formação de agregados que são de difícil solubilização mesmo se aquecidos. Açúcares, polissacarídeos, alguns álcoois, cloreto de potássio e cloreto de sódio retardam a hidratação da goma, enquanto que a acidez abaixo de pH 3,0 aumenta a hidratação. Geralmente temperaturas entre $50^{\circ}$ e $80^{\circ}$ C são necessárias para uma completa solubilização (MORAIS et al, 1989).

Todas as frações das carragenas são solúveis em leite aquecido mas algumas são mais afetadas pela presença de cálcio. No resfriamento estas soluções geleificam-se e adquirem consistência, dependendo da sua concentração e da sensibilidade do material aos íons cálcio. A lambda carragena, que é insensível aos íons cálcio e potássio, é solúvel em leite quente ou frio produzindo um grau efetivo de espessamento. A kappa e iota carragenas são insolúveis em leite frio, podendo ser usadas associadas à fosfatos como espessantes (GLICKSMAN, 1983b).

\subsubsection{Reatividade com Proteínas}

A reatividade com as proteínas é comum a todos os polissacarídeos sulfatados, por serem polímeros carregados negativamente ou poliânions em uma ampla faixa de $\mathrm{pH}$, são capazes de formar complexos com polímeros carregados 
positivamente, como as moléculas de proteína. $\mathrm{O}$ mecanismo desta interação pode ser observado na Figura 2 (GLICKSMAN, 1983b). Acima do ponto isoelétrico da proteína, ambas as moléculas estarão com cargas negativas e a reação não ocorre devido a repulsão eletrostática (MORAIS et al, 1989), porém qualquer íon polivalente presente pode atuar como ponte entre os grupos carboxílicos carregados negativamente na proteína e os ésteres sulfatos do polissacarídeo. A um $\mathrm{pH}$ inferior ao ponto isoelétrico da proteína, interações eletrostáticas semelhantes ocorrem entre o éster sulfato do polissacarídeo e os amino grupos carregados positivamente da proteína. Graus intermediários ou transacionais de associação também são encontrados em valores de $\mathrm{pH}$ entre estes dois pontos.

As carragenas reagem com a fração caseínica tanto no $\mathrm{pH}$ normal do

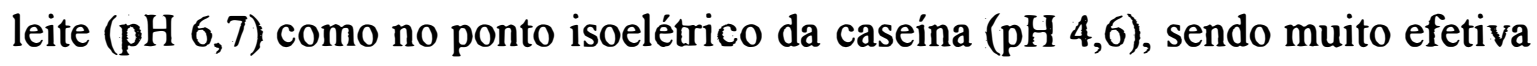
na estabilização dos produtos a base de leite. No leite puro, as frações $\alpha$ - e $\beta$ caseínas, sensíveis ao cálcio, são estabilizadas por uma terceira fração, a $\kappa-$ caseína. Se esta última for removida ou inativada, os componentes da caseína que forem sensíveis ao cálcio, irão reagir com os íons cálcio do leite e coagular-se ou precipitar-se. As carragenas, mais especificamente a kappa carragena, ao reagir com a caseína é tão efetiva quanto a $\kappa$-caseína em estabilizar as frações da caseína sensíveis ao cálcio. 
Proteino

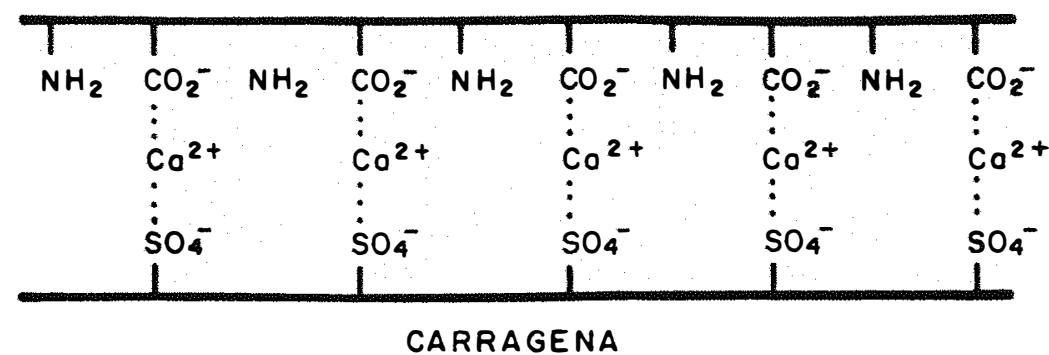

$A$
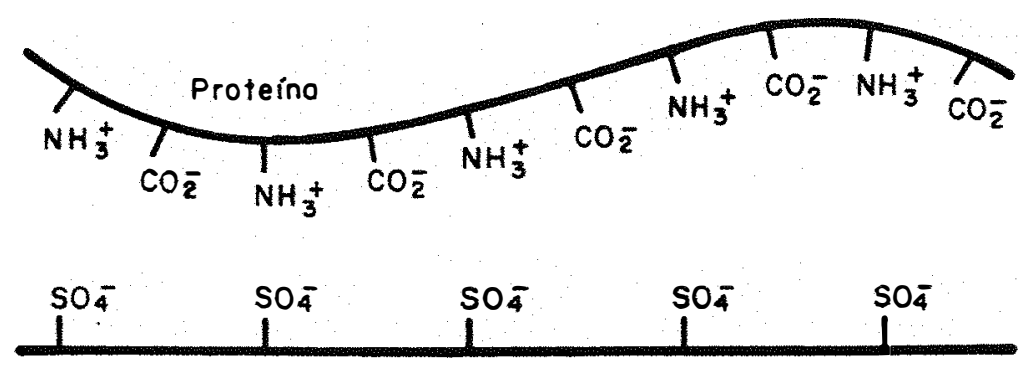

CARRAGENA

$B$

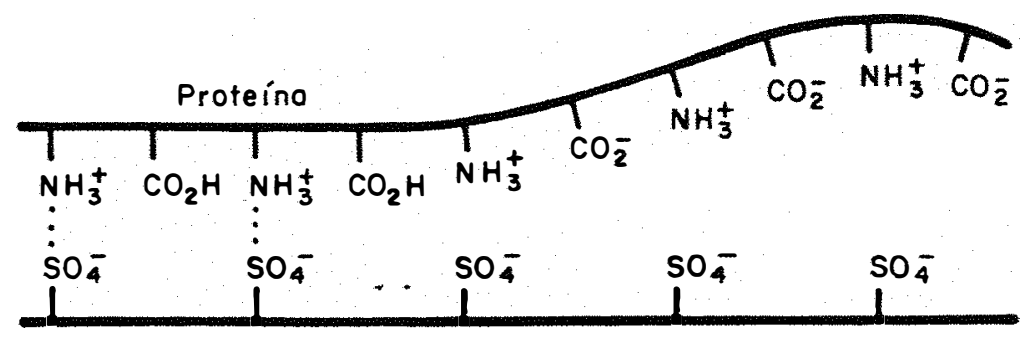

CARRAGENA

C

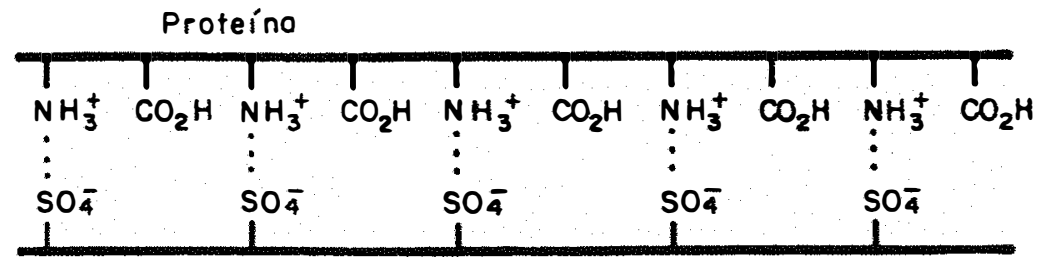

CARRAGENA

$D$

FIGURA 2- Interações iônicas entre carragenas e proteínas (GLICKSMAN, 1983b). 
As carragenas têm uma interação eletrostática muito especifica com o cálcio e as proteínas do leite, principalmente o caseinato, formando complexos tridimensionais responsáveis pela textura e estabilização do leite. Com a kappa e a iota carragenas existe um efeito geleificante em água e devido aos cátions presentes na própria carragena ou cátions presentes no leite (cálcio e potássio), ocorre um aumento da força do gel. Esta interação com a proteina é ainda reforçada pelo fato de que a lambda carragena, não geleificável em água sob nenhuma circunstância, forma géis com o leite em concentrações ao redor de 0,2\% (GLICKSMAN, 1983b).

\subsubsection{Efeitos Nutricionais e Tóxicos}

Os impactos nutricionais das carragenas, principalmente os seus efeitos sobre o crescimento corporal e digestibilidade do alimento, foram analisados por BLANQUAT \& KLEIN (1984), concluíndo que as de alto peso molecular não poderiam ser consideradas como nutrientes. Elas exercem efeitos no trânsito digestivo e na excreção fecal a partir da dosagem de $1 \%$ na dieta, aumentando o volume do bolo fecal e podendo também reduzir o colesterol plasmático (REDDY et al, 1980). Está claro que estes compostos manifestam, mesmo a doses moderadas de 1 a $2 \%$ na dieta, a ocorrência de um certo número de efeitos sobre a fisiologia digestiva, sendo estes largamente evidenciados quando dosagens superiores a 5\% são utilizadas (BLANQUAT \& KLEIN, 1984).

A tabela publicada pela ORGANIZATION MONDIALE DE LA SANTÉ (1976), indica a dose letal (DL 50) da carragena na forma sódica, de uma suspensão a $25 \%$ em óleo de milho anidro, para várias espécies animais após a administração intragástrica. Dos animais analisados a dose letal mais baixa foi para o coelho $(4.670-5.430 \mathrm{mg} / \mathrm{kg})$ e a mais alta para a fêmea do camundongo 
(8.730-9.670 $\mathrm{mg} / \mathrm{kg}$ ). Segundo LORENA \& FERREIRA (1989), a dose diária admissivel (DDA) é de 0-50 mg/kg de peso corpóreo.

De acordo com outras revisões sobre aditivos alimentares GRAS ("Generally Recognized As Safe"), o FDA ("Food and Drug Administration") coletou e revisou a literatura cientifica sobre as carragenas na forma sódica e cálcica como ingrediente alimentar e realizou estudos teratológicos com as mesmas. Nenhum resultado adverso foi reportado e as carragenas foram aprovadas como aditivo regular sendo que as usadas em alimentos têm pesos moleculares de 100.000 a 500.000 .

A carragena e seus sais são classificados como GRAS para serem usados em níveis BPF ("Boas Práticas de Fabricação"), ou seja, quantidade de uma substância adicionada ao alimento não excedendo a razoavelmente requerida para cumprir seus efeitos desejados (GLICKSMAN, 1983b). Segundo SIMÃO (1985), seu código para rotulagem é EP.X.

De acordo com SANTIAGO (1971), os aditivos tipo espessantes em laticínios, têm seu emprego autorizado em certos tipos de queijos e em doce de leite, se for indispensável à adequação da tecnologia de fabricação, estiver registrado em órgão competente, for utilizado em quantidade estritamente necessária à obtenção do efeito desejado e respeitado o limite máximo prédeterminado. São classificados como aditivos para alimentos, "todas as substâncias intencionalmente adicionadas ao mesmo com a finalidade de conservar, intensificar ou modificar suas propriedades, desde que não prejudique o seu valor nutritivo". 


\subsection{Funções e Aplicações}

A estrutura química das carragenas mostra que a sua molécula é um polieletrólito com carga predominantemente negativa. Esta propriedade explica as múltiplas e possíveis interações com outros compostos que são afetados por ligação hidrofilica, interações iônicas e por forças de Van der Waals. Os resultados destas interações, modificam usualmente as características do sol ou do gel e fornecem a base da aplicabilidade tecnológica em alimentos. Assim sendo, as carragenas podem ser utilizadas para a formação de géis, para formarem suspensões, para a estabilização de emulsões, para controlarem a sinérese e para funcionarem como espessantes. Uma funcionalidade específica pode ser observada quando as carragenas são introduzidas em sistemas alimentícios contendo o leite ou outras proteínas dispersas na forma coloidal.

Como as carragenas possuem uma gama de propriedades diversas, são utilizadas em inúmeras aplicações, todavia a maior delas é na indústria alimentar permitindo a obtenção de excelentes resultados em alimentos aquosos a base de proteínas (MORAIS, 1989). Devido ao seu baixo teor calórico, são ingredientes importantes para a fabricação de produtos dietéticos ou "light", existindo atualmente uma grande demanda de mercado para este tipo de produtos (ANTUNES \& CANHOS, 1987). Segundo BULLENS et al (1994), para este tipo de queijo, é necessário adicionar ingredientes que possam substituir os efeitos que a gordura exerce na textura da massa.

BRUMMEL \& LEE (1990), afirmam serem os hidrocolóides úteis, especialmente para o fabrico de queijos processados com baixo teor de gordura. Os hidrocolóides, já recomendados como estabilizantes em queijos processados pasteurizados desde os anos 30, somente a partir de 1950, encontraram um mercado consumidor receptivo para estes produtos de baixa caloria. O uso dos 
hidrocolóides em níveis moderados, permite reter grande quantidade de umidade enquanto mantém uma textura semelhante a dos produtos convencionais.

Segundo BULLENS et al (1994), misturas de carragenas e celulose microcristalina podem ser usadas para produzir queijos "light" naturais sob a aprovação da FDA. Os demais ingredientes, tradicionais na fabricação de queijos, são devidamente adaptados para uma maior funcionalidade dos hidrocolóides e melhoria do sabor dos produtos obtidos. Deve-se aumentar ligeiramente a quantidade de coalho, se possível, aconselha-se o seu uso quando é composto de $100 \%$ de quimosina. O cálcio, de importante função na coagulação do leite e na interação proteína-carragena, deve ser adicionado sob a forma de cloreto de cálcio, para dar maior firmeza ao coágulo que será formado. Os efeitos combinados destes ingredientes serão importantes, para que a coagulação se proceda dentro do tempo normal e permita uma distribuição mais uniforme das partículas da mistura de carragena e de celulose microcristalina. Esta última forma partículas esféricas que simulam as características de corpo e "mouthfeel" dos glóbulos de gordura da mesma forma que estes glóbulos atuariam no queijo convencional, as suas partículas entremeadas no coágulo agem como uma barreira física suavizando a rede de caseina. A fase aquosa é então estruturada pelo controle do tipo de carragena, que interage diretamente com os ingredientes do leite. O tipo e a concentração dos hidrocolóides na formulação irão controlar a textura, a deformabilidade e o derretimento do queijo.

Os rendimentos calculados para estes sistemas foram considerados $10 \%$ maiores do que o controle, podendo ser atribuído à maior retenção de umidade proporcionada pelas propriedades do complexo caseína/carragena. Com conteúdo de $34 \%$ de proteína e $11 \%$ de gordura, forma-se um complexo muito rígido entre ambas e de carater inelástico. Com a adição da carragena ocorre uma suavização da estrutura e um aumento da deformabilidade por interferir na associação entre 
as moléculas da caseína. Porém, um excesso de carragena pode afetar adversamente a formação do coágulo durante a coagulação.

O queijo Cheddar com $11 \%$ de gordura e sem hidrocolóides, apresentou a sua matriz muito densa e contínua quando comparado ao controle com $34 \%$ de gordura. $\mathrm{A}$ inclusão da carragena e da celulose microcristalina permitiu à proteína do queijo adquirir uma estrutura porosa, tornando a sua microestrutura semelhante a do controle.

Outra utilização foi obtida por WITT (1986), que faz referência a um método de fabricação de queijos com o uso de carragenas, com o objetivo de aprimorar o método convencional pelo fato do uso dos hidrocolóides melhorarem a formação do coágulo, provendo uma textura desejável e uma maior retenção dos nutrientes no queijo. Neste aspecto, especial referência é feita para a fabricação dos queijos tipo Cottage obtidos por acidificação direta, e tipo "Blanco Americano".

No método convencional o soro contém até $45 \%$ dos nutrientes do leite utilizado para a fabricação do queijo, incluindo até $25 \%$ das proteínas disponíveis, como a albumina e a globulina. Este método preocupa-se primariamente com o processo básico de formação do coágulo, onde são retidos os nutrientes do leite, especialmente as proteínas, que no método convencional seriam perdidos no soro.

Sabe-se que o aumento da temperatura do leite $\left( \pm 82^{\circ} \mathrm{C}\right)$ para a obtenção do coágulo por precipitação ácida na fabricação do queijo "Blanco Latino Americano", causa um acréscimo no conteúdo de proteínas no coágulo resultante, além de uma maior retenção de umidade. Porém, além destas vantagens do ponto de vista de rendimento, também ocorre uma modificação na textura deste coágulo, que torna-se indesejável e macio. Neste caso, o uso de carragenas dispensa o uso de altas temperaturas (de preferência não superiores a $49^{\circ} \mathrm{C}$ ), mantendo os altos teores de nutrientes retidos, sem prejuízo à textura do coágulo. 
Dois fatores importantes que influenciam a efetividade deste método, são o teor de cálcio do leite e o seu pH no momento da adição da carragena. $\mathrm{O}$ nível de cálcio solubilizado no leite no momento da coagulação é de grande importância na captura das proteínas que seriam perdidas no soro. Baixos níveis de cálcio solúvel iriam interferir na formação da rede de caseína e levariam a rendimentos reduzidos na coagulação. A adição controlada de cloreto de cálcio deve ser realizada, caso seja necessária, para correção do seu nível a teores desejáveis entre 50 e 100ppm. O pH do leite deve estar entre 6,0 e 6,5 quando da introdução da carragena para que esta apresente uma maior reatividade (WITT, 1986).

Na fabricação do queijo Cottage por acidificação direta, o rendimento foi superior em 10 e $17 \%$ quando adicionou-se 250 e 500ppm respectivamente de carragenas ao leite, e o coágulo apresentou-se com corpo e sabor desejáveis. A solubilização da carragena em água a $66^{\circ} \mathrm{C}$ foi rápida, além de conduzir a um maior rendimento em queijo (WITT, 1986).

Segundo WHISTLER \& DANIEL (1985), a adição de carragenas aos leites achocolatados previne a precipitação do chocolate e, em sobremesas congeladas, age como um inibidor da cristalização do gelo. Graças ao seu poder estabilizante é utilizada em pudins de leite e em produtos a base de queijo. 


\section{MATERIAIS E MÉTODOS}

\subsection{Materiais}

\subsubsection{Matéria-Prima}

A matéria-prima utilizada foi o leite crú integral, proveniente do departamento de Zootecnia da ESALQ/USP.

\subsubsection{Agente Coagulante}

$O$ agente de coagulação utilizado foi o coalho líquido, de origem animal, fornecido pela DANILAC.

\subsubsection{Fermento Lático}

Utilizou-se o fermento lático mesofilico homofermentativo tipo "O" (DVS R-70 Chr. Hansen, DK) composto de Lactococcus lactis subsp. lactis e Lactococcus cremoris subsp. cremoris.

\subsubsection{Carragenas}

As carragenas utilizadas foram fornecidas pela Germantown do Brasil e pela SANOFI (SBI) do Brasil, sob os respectivos nomes comerciais Gerba NuKreme e Satiagel OF 10 BR. 


\subsubsection{Outros Ingredientes}

\subsubsection{Cloreto de Cálcio}

O cloreto de cálcio $\left(\mathrm{CaCl}_{2}\right)$ foi utilizado na forma de solução aquosa a $50 \%(\mathrm{p} / \mathrm{v})$.

\subsubsection{Cloreto de Sódio}

O cloreto de sódio utilizado foi o sal grosso comum da marca Cisne.

\subsection{Métodos}

\subsubsection{Amostragem}

As amostras do leite foram retiradas no momento da sua recepção e a dos queijos, feitas em forna de cunha e maceradas em gral até uniformização. Ambas amostragens foram realizadas de acordo com as especificações dos métodos analíticos do LANARA (1981).

\subsubsection{Métodos Analíticos}

\subsubsection{1. pH}

A leitura do $\mathrm{pH}$ do leite e do queijo foram determinadas em potenciômetro digital da marca Digimed, modêlo DMPH-2.

\subsubsection{Acidez}

A acidez do leite e dos queijos foi determinada por titulação com solução titrisol ou de $\mathrm{NaOH} 0,1 \mathrm{~N}$, tendo a fenolftaleína como indicador (solução a $1 \% \mathrm{p} / \mathrm{v}$ ), de acordo com as descrições do LANARA (1981). Os resultados foram 
expressos em graus Dornic $\left({ }^{\circ} \mathrm{D}\right)$ para o leite e em porcentagem de ácido lático para os queijos $(\mathrm{p} / \mathrm{p})$.

\subsubsection{Densidade do Leite}

A densidade do leite foi determinda a $15^{\circ} \mathrm{C}$, utilizando-se o termolactodensímetro de Quevenne, segundo LANARA (1981).

\subsubsection{Gordura}

O teor de gordura do leite, do soro após o corte e do queijo foram determinados pelo método de Babcock (NEWLANDER \& ATHERTON, 1964).

\subsubsection{Gordura no Extrato Seco (GES)}

Nos queijos, o teor de gordura no extrato seco foi obtido pela seguinte relação:

$$
\text { GES }=\frac{\% \text { de gordura }}{\% \text { de EST }} \times 100
$$

\subsubsection{Proteína}

Os teores de proteína do leite e dos queijos foram determinados pelo método de micro Kjeldahl (INTERNATIONAL DAIRY FEDERATION, 1962), e a proteína bruta calculada, multiplicando-se o nitrogênio total pelo fator 6,38.

\subsubsection{Umidade}

O teor de umidade dos queijos foi determinado de acordo com a metodologia descrita pela A.O.A.C. (1990), baseando-se na técnica de secagem em estufa a $100-105^{\circ} \mathrm{C}$ e pesagem até peso constante. 


\subsubsection{Extrato Seco Total (EST)}

No leite o EST foi determinado segundo BEHMER (1991), a partir das determinações de gordura e densidade, utilizando-se a fórmula:

$$
\mathrm{EST} \%=\mathrm{G} / 5+\mathrm{D} / 4+\mathrm{G}+0,26
$$

Nos queijos foi determinado pela seguinte relação:

$$
\mathrm{EST} \%=100-\% \text { umidade }
$$

\subsection{Elaboração do Queijo Minas Frescal}

Todos os processamentos foram realizados no Laboratório do setor de Leite e Derivados do Departamento de Ciência e Tecnologia Agroindustrial da ESALQ/USP, totalizando 5 ensaios, com volume de 6 litros de leite/ensaio para cada tratamento.

Dois diferentes fluxogramas de processamento foram avaliados, a saber: o processo tradicional (codificado como "TRAD") e o modificado, este último envolvendo fundamentalmente a utilização das duas amostras de carragenas de diferentes origens (codificados como "GE" para a carragena da Germantown e "GEL" para a da Sanofi). Os fluxogramas de produção constam da Figura 3 e as condições experimentais são apresentadas em seguida. 
MÉTODO TRADICIONAL

recepção do leite

$\Downarrow$

pasteurização

$\Downarrow$

resfriamento

$\Downarrow$

adição de:

cloreto de cálcio

fermento

coalho

$\Downarrow$

coagulação

$\Downarrow$

corte

$\Downarrow$

agitação/repouso

$\Downarrow$

dessoragem

$\Downarrow$

salga

$\Downarrow$

enformagem

$\Downarrow$

armazenamento
MÉTODO MODIFICADO

recepção do leite

$\Downarrow$

pasteurização

$\Downarrow$

resfriamento

$\Downarrow$

adição de:

cloreto de cálcio

CARRAGENA

fermento

coalho

$\Downarrow$

coagulação

$\Downarrow$

corte

$\Downarrow$

agitação/repouso

$\Downarrow$

dessoragem

$\Downarrow$

salga

$\Downarrow$

enformagem

$\Downarrow$

armazenamento

FIGURA 3 - Fluxogramas do processamento do queijo Minas Frescal pelos métodos tradicional e modificado. 
$\mathrm{Na}$ recepção, o leite foi caracterizado quanto a sua composição físicoquímica. A pasteurização, realizada a $68^{\circ} \mathrm{C}$ por 2 minutos, foi feita no tanque de processo.

Após resfriamento a $32^{\circ} \mathrm{C}$, adicionou-se os seguintes coadjuvantes:

- cloreto de cálcio: solução a $50 \%$, na proporção de $40 \mathrm{ml} / 100$ litros de leite;

- carragenas: foram adicionadas segundo as recomendações fornecidas pelos respectivos fabricantes, sendo a da Sanofi na dosagem de $0,15 \%$ do peso do produto final, e a da Germantown na de $0,18 \%$ do total do leite a ser processado;

- fermento lático: $0,5 \%$ em relação ao volume de leite;

- coalho: no momento da sua utilização foi diluído na proporção de 1:5 em água destilada morna. A quantidade utilizada foi a necessária para coagular o leite em aproximadamente 40 minutos.

Para a determinação do momento do corte optou-se pelo procedimento convencional introduzindo-se uma espátula de maneira perpendicular na coalhada abrindo-a numa fenda retilínea e expondo sua estrutura que podia então ser avaliada. Quando a espátula era retirada sem nenhuma aderência de massa e a coalhada apresentava-se firme e com a exsudação de um soro límpido e esverdeado, estava no ponto de corte (KEATING, 1969). Concomitantemente, o mesmo tempo de coagulação era determinado para os demais tanques de fabricação dentro do mesmo processamento ou repetição.

A temperatura de coagulação foi de $32^{\circ} \mathrm{C}$ e o corte, efetuado de maneira a obter-se grãos com $1,5 \mathrm{~cm}$ de aresta. A agitação foi iniciada 10 minutos após o corte, e para a determinação do ponto de massa foi mantido um tempo pré determinado de 50 minutos e constante para todos os processamentos, alternandose mexedura e repouso parcial ( 1 minuto de mexedura e 3 de repouso). Após a dessoragem parcial foi realizada a salga na massa com a adição de $\mathrm{NaCl}(4 \%$ do 
peso do queijo). A enfornagem foi feita em fôrnas de fundo totalmente perfurado, para a melhor eliminação do soro. Finalizada esta operação, as fônnas foram deixadas em repouso por 30 minutos, para que ocorresse a drenagem do soro residual. Após este tempo os queijos foram virados de lado e deixados em repouso por 60 minutos, sendo então virados novamente e deixados em repouso por outro período de 60 minutos. Em seguida eram levados para câmara fria a \pm 10 ${ }^{\circ} \mathrm{C}$, onde permaneceriam nas fôrmas até o dia seguinte. A seguir os queijos foram envoltos por embalagens plásticas (trocadas diariamente), pesados e virados de lado a cada $24 \mathrm{hs}$, até completarem 7 dias.

Para os três tratamentos, um com a tecnologia tradicional (TRAD) e dois com a modificada (GE e GEL), os queijos foram submetidos às analises fisico-químicas com 1 dia após a fabricação e 7 dias após o armazenamento a $10^{\circ} \mathrm{C}$.

\subsection{Rendimento}

A eficiência de cada um dos processamentos foi avaliada mediante a relação do volume inicial de leite utilizado na fabricação e o peso dos queijos obtidos.

\subsection{Análise Sensorial}

A análise sensorial dos queijos obtidos pelos diferentes métodos foi feita com 1 dia e com 7 dias após sua elaboração. Aplicou-se o Teste Triangular com o objetivo de verificar se existem diferenças significativas entre as amostras que sofreram tratamentos diferentes. Ele consta da apresentação de duas amostras 
ao provador, que deve detectar a diferente num conjunto de três que são servidas ao mesmo tempo.

O número de respostas corretas necessárias para estabelecer diferenças significativas são encontrados na Tabela 11, no apêndice (MORAES, 1993), para vários números de comparações efetuadas aos níveis de significância de $5 \%, 1 \% \mathrm{e}$ $0,1 \%$, baseados nos testes do $X^{2}$ (qui-quadrado). De acordo com o número de respostas corretas pode-se afirmar, se existe ou não, diferença detectável entre as amostras testadas ao nível de significância desejado (MORAES, 1993).

Foi realizada uma avaliação por 20 a 40 provadores que não precisaram ser treinados mas que no momento da análise receberam as orientações pertinentes à condução do teste.

As avaliações das amostras dos queijos, foram realizadas em cabines individuais, sendo as amostras codificadas com 3 dígitos e apresentadas de forma ordenada e homogênea aos provadores, sob luz vermelha, a temperatura ambiente e em quantidade suficiente. $O$ modelo de ficha para a avaliação sensorial empregado encontra-se no apêndice, no Formulário 1. As amostras foram distribuídas a fim de que fossem comparados os queijos fabricados com cada uma das duas carragenas com a amostra controle obtida pelo processo tradicional.

\subsection{Análise Estatística}

A partir dos resultados obtidos foram formuladas duas hipóteses, a da nulidade e a alternativa, pelas quais ao menos duas médias diferiam entre sí. As hipóteses foram testadas na análise de variância através do teste $F$, que indica se houve diferença estatística entre as médias devidas ao tratamento, levando-se em consideração o erro experimental. Quando rejeitada a hipótese da nulidade, aplicou-se o teste de Tuckey, ao nível de $5 \%$ ou $1 \%$ de probabilidade, para comparação múltipla entre as médias (PIMENTEL-GOMES, 1985). 


\section{RESULTADOS E DISCUSSÃO}

No presente trabalho foram estudadas as tecnologias tradicional e a modificada, nas quais existem algumas etapas diferentes. Na modificada, adicionou-se as carragenas procurando verificar a sua influência na dessoragem, rendimento e possíveis alterações sensoriais, enquanto na tradicional os queijos serviram de controle do processo.

\subsection{Características Aparentes dos Queijos}

Embora de utilização industrial em inúmeros países no mundo todo, são poucos os trabalhos de pesquisa versando sobre a utilização das carragenas na fabricação de queijos, particularmente em nosso país.

A adição das carragenas, apesar de causar uma alteração na superficie da coalhada, com o tratamento GE apresentando um aspecto granuloso e o GEL um aspecto espumoso, abaixo desta camada superficial a coalhada mostrava-se nornal em ambas as tecnologias e não foi observada nenhuma diferença visual no ponto de coagulação, resistência ao corte, coloração do soro ou consistência do grão.

Neste trabalho foram mantidas as quantidades de cloreto de cálcio normalmente recomendadas para a fabricação de queijos (FURTADO \& LOURENÇO-NETO, 1994) e não foram observadas alterações visuais de nenhum tipo. 


\subsection{Análises Físico-Químicas}

\subsubsection{Leite}

O leite utilizado foi sempre proveniente de uma mesma ordenha para cada processamento ou repetição de forma a evitar a interferência de outros fatores na comparação dos resultados. As características físico-químicas do leite utilizado para os cinco processamentos podem ser observados na Tabela 2.

TABELA 2- Composição físico-química do leite crú utilizado para a elaboração dos queijos.

\begin{tabular}{lccrrr}
\hline & \multicolumn{5}{c}{ Repetições } \\
\cline { 2 - 6 } Parâmetros & 1 & 2 & 3 & 4 & 5 \\
\cline { 2 - 6 } & 15,0 & 16,5 & 15,5 & 18,5 & 17,0 \\
Acidez $\left({ }^{\circ} \mathrm{D}\right)$ & 6,72 & 6,58 & 6,63 & 6,59 & 6,66 \\
pH & 3,50 & 2,60 & 3,20 & 3,15 & 3,30 \\
Gordura (\%) & 3,15 & 3,10 & 2,77 & 2,98 & 2,89 \\
Proteína (\%) & 12,01 & 11,45 & 11,42 & 12,14 & 11,69 \\
Extrato Seco Total (\%) & 1030,6 & 1032,5 & 1029,3 & 1032,4 & 1029,9 \\
Densidade (g/l) & & & & &
\end{tabular}

A composição do leite varia com a raça, alimentação, individualidade, período de lactação, época do ano e muitos outros fatores (CARVALHO, 1977). Os componentes do leite têm diferentes valores para a fabricação de queijos, alguns são absolutamente necessários como a gordura e a proteína, enquanto outros têm pouca influência no processamento dos queijos. As porcentagens de 
gordura e proteína (caseína) determinam principalmente o rendimento do queijo, e a proporção entre estes elementos (relação gordura/caseína), determina a sua composição (FURTADO, 1975). A quantidade de sólidos do leite que irá passar ao queijo é determinada grandemente pelos seus teores de gordura e proteína, mantendo-se adequadas as condições de fabricação. A composição do leite utilizado foi bastante semelhante a do leite utilizado por FURTADO et al (1980a) e FURTADO \& WOLFSCHOON-POMBO (1979a), permitindo a obtenção de queijos com composição semelhante.

\subsubsection{Soro}

\subsubsection{Acidez, pH e teor de gordura}

De acordo com os dados de $\mathrm{pH}$ e de acidez observados no soro após o corte e apresentados na Tabela 3, os mesmos estão dentro dos padrões médios esperados para a fabricação deste tipo de queijo (FURTADO et al, 1980a; FURTADO \& WOLFSCHOON-POMBO, 1979a), indicando que as carragenas não tiveram influência na atividade da cultura lática.

TABELA 3 - Valores médios de $\mathrm{pH}$, acidez e gordura do soro após o corte da massa*.

\section{Determinações}

\begin{tabular}{lccl}
\cline { 2 - 4 } Tratamentos & $\mathrm{pH}$ & Acidez $\left({ }^{\circ} \mathrm{D}\right)$ & Gordura (\%) \\
\hline TRAD & 6,41 & 11,60 & 0,25 \\
GE & 6,39 & 11,46 & 0,31 \\
GEL & 6,43 & 11,07 & 0,29
\end{tabular}

*Médias de 5 repetições 
Os valores de gordura no soro encontrados neste experimento mostraram que não houve diferença entre os tratamentos com carragena e o controle. Estes valores encontram-se ligeiramente abaixo dos teores normalmente encontrados para a fabricação deste tipo de queijo (FURTADO et al, 1980a; FURTADO \& WOLFSCHOON-POMBO, 1979a; WOLFSCHOON-POMBO \& FURTADO, 1977), o que pode ser explicado em função da adoção de procedimentos tecnológicos adequados.

As diferenças encontradas na composição do soro são atribuídas basicamente ao método de coagulação, progresso na fermentação da lactose e principalmente no tratamento da coalhada. Quando o leite é transformado em coalhada quase toda a proteína e gordura são retidas no coágulo e pequenas quantidades são perdidas no soro. As variações que ocorrem nas perdas de gordura devem-se basicamente a diferenças nos métodos de fabricação dos queijos. É impossível evitar-se a perda de gordura durante a fabricação de queijos. Quando ocorre a coagulação da caseína os glóbulos de gordura são aprisionados ou retidos na massa justamente no lugar exato em que encontravam-se no momento da coagulação e com o corte muitos glóbulos são expostos em cada superficie cortada, desprendendo-se dos grãos durante a sua manipulação, flutuando no soro e perdendo-se nele (FURTADO \& WOLFSCHOON-POMBO, 1979a). 


\subsubsection{Queijos}

\subsubsection{Acidez e pH}

Os valores de $\mathrm{pH}$ e acidez para os queijos com 1 e 7 dias são apresentados na Tabela 4 .

TABELA 4 - Resultados das análises de acidez e pH dos queijos*.

\begin{tabular}{lcccc}
\hline & \multicolumn{5}{c}{ Determinações } \\
\cline { 2 - 5 } Tratamentos & \multicolumn{3}{c}{ 1 dia } & \multicolumn{3}{c}{7 dias } \\
\cline { 2 - 5 } & \% ác. lático & $\mathrm{pH}$ & \% ác. lático & $\mathrm{pH}$ \\
\hline TRAD & 0,26 & 4,67 & 0,28 & 4,53 \\
GE & 0,25 & 4,66 & 0,27 & 4,51 \\
GEL & 0,26 & 4,69 & 0,27 & 4,54 \\
DMS (5\%) & $-\ldots$ & --- & $-\ldots$ & $\cdots$ \\
\hline
\end{tabular}

*Médias de 5 repetições.

Como já referido anteriormente para o $\mathrm{pH}$ e acidez do soro na fabricação dos queijos, não foram observadas diferenças entre os tratamentos para estes parâmetros nos queijos e a acidificação transcorreu de forma normal em todos eles. Por meio da Figura 4 pode-se visualizar nitidamente uma redução do $\mathrm{pH}$ dos queijos após os 7 dias de armazenamento a $10^{\circ} \mathrm{C}$ em relação ao primeiro dia. Na Figura 5 pode ser visualizado o aumento da acidez dos queijos após os 7 dias de fabricação em relação ao primeiro dia. Os valores de $\mathrm{pH}$ e acidez mostraram-se dentro dos padrões médios esperados (FURTADO et al,1980a; FURTADO et al, 1980b; SAITO \& SCHIFTAN, 1978). 


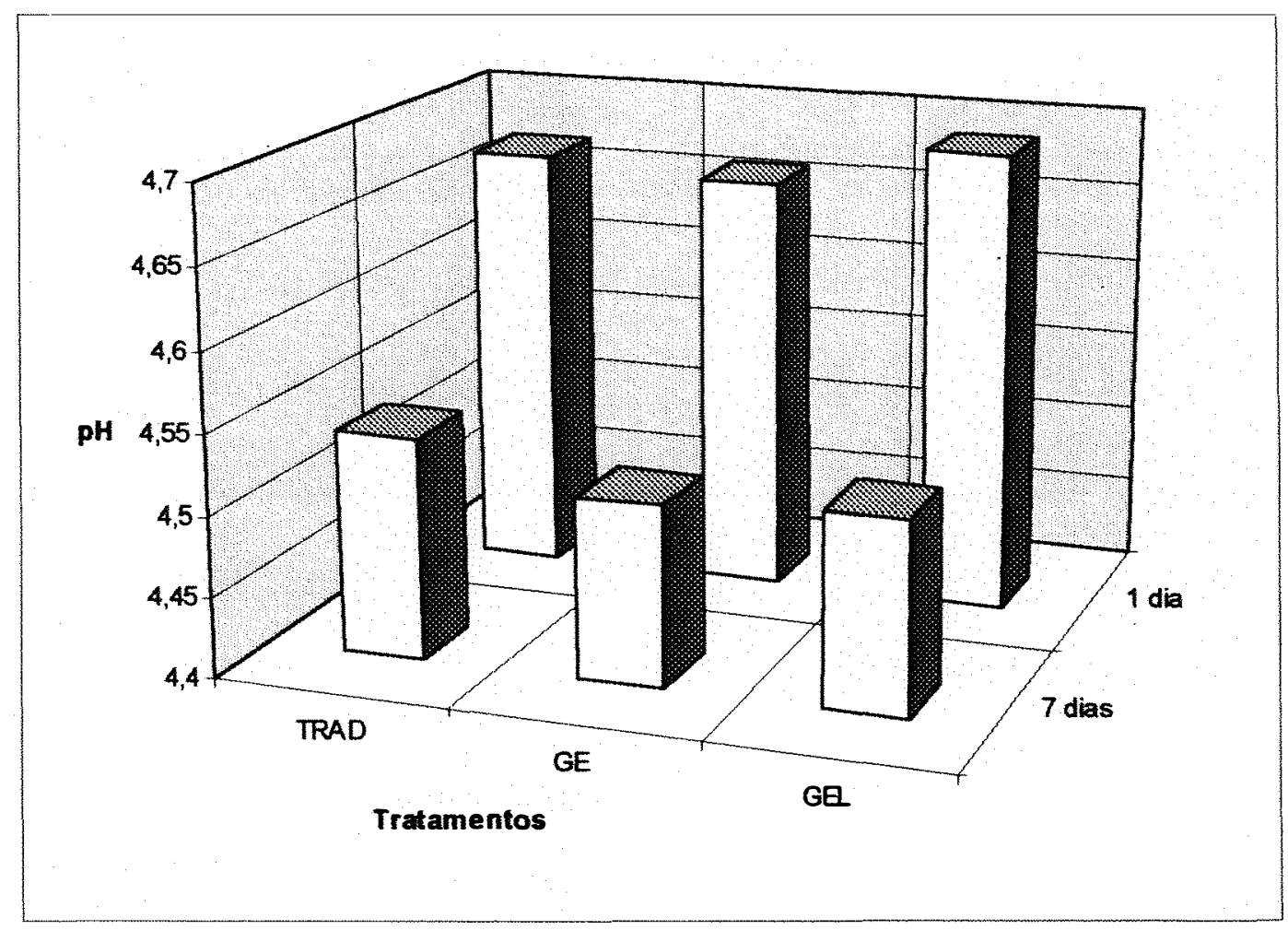

FIGURA 4- Valores de pH dos queijos para os três tratamentos observados com 1 e 7 dias (médias de 5 repetições). 


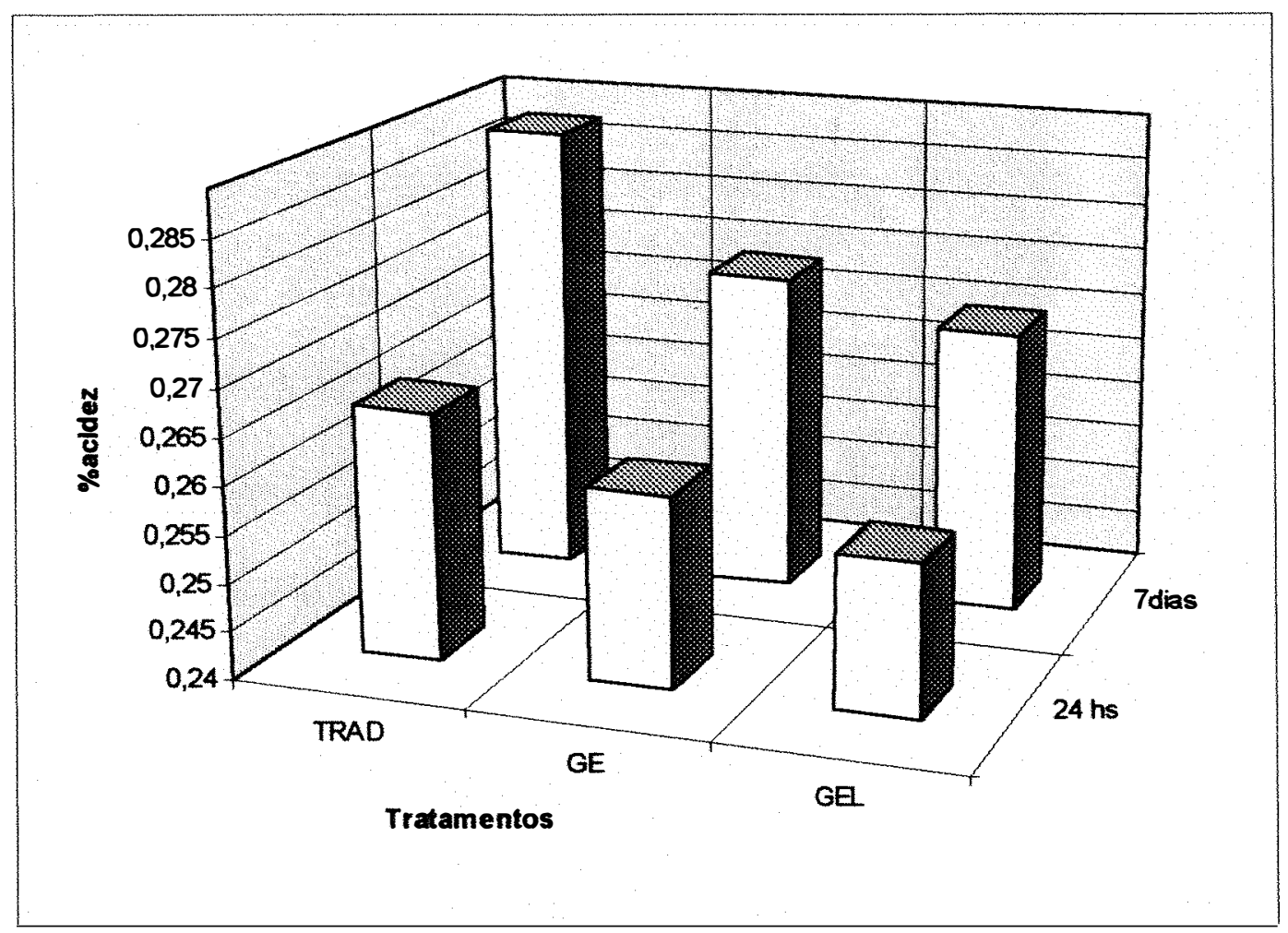

FIGURA 5- Valores de acidez dos queijos para os três tratamentos observados com 1 e 7 dias (médias de 5 repetições). 


\subsubsection{Proteínas e Gordura}

Os resultados das análises químicas dos queijos com 1 e 7 dias são apresentados na Tabela 5 .

TABELA 5 - Resultados das análises químicas dos queijos*.

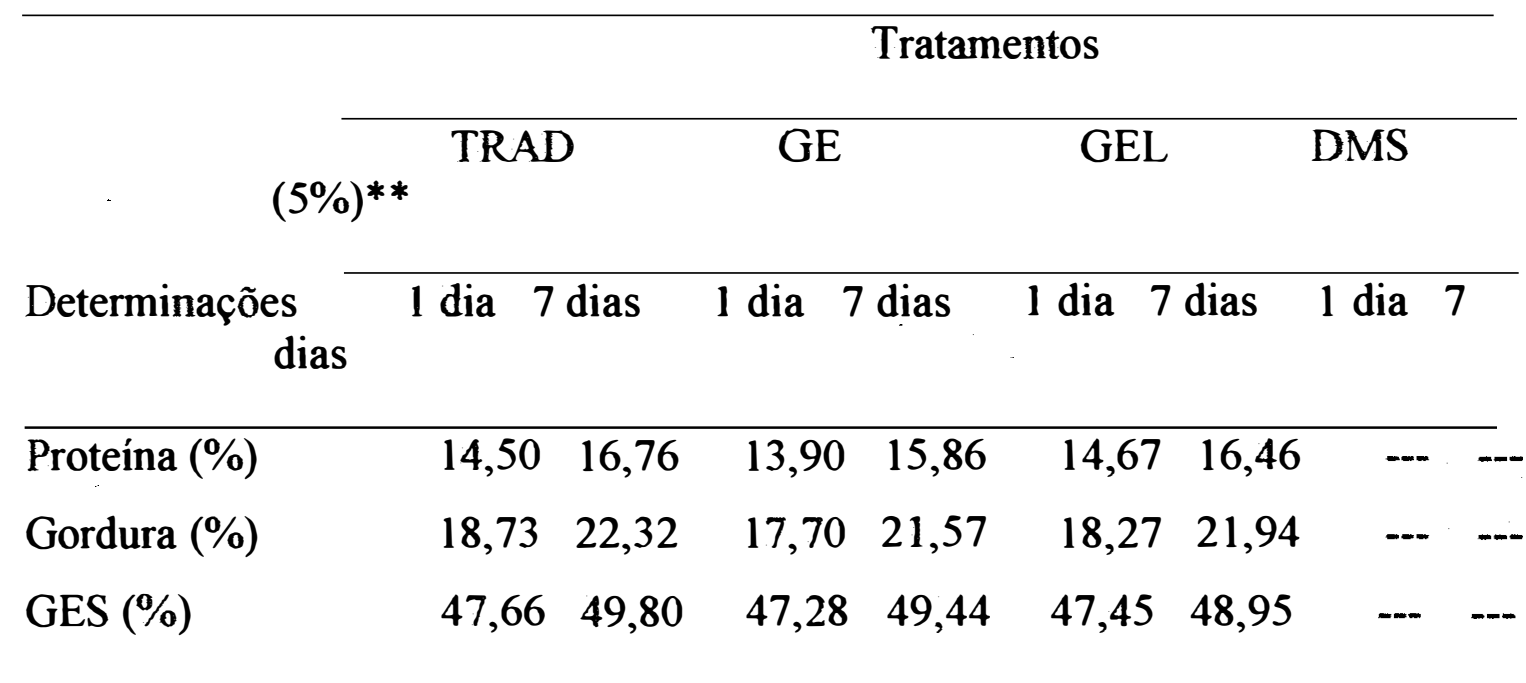

*Médias de 15 repetições.

**DMS = diferença mínima significativa.

Após a análise estatística dos dados observou-se que não houve diferença significativa entre os três tratamentos (TRAD, GE e GEL) para os parâmetros proteína, gordura e gordura no extrato seco (GES). WITT (1986), em seu trabalho relatou que o uso de carragenas, especificamente a iota-carragena sódica, na obtenção de um coágulo por acidificação direta reduzia a sua sinérese e o teor de proteínas remanescentes no soro. Ela exercia a mesma função de um tratamento térmico que causaria a precipitação das proteínas do soro sobre a $\kappa$ caseína, levando a uma maior retenção destas no coágulo, porém este tratamento térmico trazia prejuízos à textura do coágulo ao passo que as carragenas, tendo a 
propriedade de reter as proteínas do soro no coágulo ao reagir especificamente com as proteínas do leite, reteriam ao menos as que no processo tradicional seriam perdidas no soro. Segundo aquele autor, ocorria uma reação entre a proteína e a carragena porém a natureza desta reação não era explicada, e quanto maior era a concentração de carragena adicionada menor era a sinérese deste coágulo e o teor de proteínas contido n o soro.

Era esperado que fossem encontradas diferenças significativas nos teores de proteína e gordura dos queijos adicionados de carragena em relação aos tradicionais. No teor de proteína esperava-se um aumento pela reatividade das carragenas com as proteínas do leite (incluindo as do soro) e no teor de gordura um aumento em função da formação de um coágulo com uma matriz mais fina ou mais entrelaçada pela presença da carragena na formação do gel com uma maior retenção dos glóbulos de gordura, porém isto não foi observado neste trabalho no nível de utilização das carragenas. Possivelmente um aumento na concentração utilizada poderia ocasionar uma resposta positiva neste sentido.

A determinação do teor de gordura no extrato seco (GES) é uma indicação da retenção de gordura no queijo independentemente do seu teor de umidade, porém do ponto de vista estatístico não houve diferença significativa entre os tratamentos, também não observada para os teores de gordura, no que diz respeito ao teor de GES.

Segundo FURTADO \& WOLFSCHOON-POMBO (1979b), a GES para o queijo tipo Minas Frescal varia entre $43,5 \%$ e $49,8 \%$, podendo a partir de $45,0 \%$ ser denominado de queijo gordo. De acordo com SAITO \& SCHIFTAN (1978), este queijo tem uma GES média de 46,0\%. Em países da Europa, como a França, o teor mínimo de GES é obrigatoriamente fixado na embalagem do produto, resultando em um melhor padrão de qualidade e servindo de orientação para o consumidor (FURTADO \& WOLFSCHOON-POMBO, 1979b). Os resultados da GES estão de acordo com os citados por estes autores. 


\subsubsection{Umidade e EST}

Os resultados das análises de umidade e extrato seco total (EST) dos queijos com 1 dia e 7 dias após armazenamento a $10^{\circ} \mathrm{C}$, são apresentadas na Tabela 6.

TABELA 6- Resultados das análises do teor de umidade e EST dos queijos*.

\begin{tabular}{lcccc}
\hline & \multicolumn{5}{c}{ Determinações } \\
\cline { 2 - 5 } Tratamentos & \multicolumn{3}{c}{1 dia } & \multicolumn{3}{c}{7 dias } \\
\cline { 2 - 5 } & Umidade (\%) & EST (\%) & Umidade (\%) & EST (\%) \\
\hline TRAD & 60,75 b & $39,24 \mathrm{a}$ & 55,16 & 44,83 \\
GE & $62,99 \mathrm{a}$ & $37,00 \mathrm{~b}$ & 56,44 & 43,55 \\
GEL & $61,55 \mathrm{ab}$ & $38,45 \mathrm{ab}$ & 55,31 & 44,88 \\
DMS (1\%)** & 1,9011 & 1,9019 & $\cdots$ & $\cdots$ \\
\hline *Médias seguidas por letras distintas diferem entre sí no nível de significância a 1\%. \\
*Médias de 15 repetições. \\
**DMS= diferença mínima significativa.
\end{tabular}

Após a análise estatística dos resultados obtidos com 1 dia observou-se que o tratamento GE mostrou-se estatísticamente significante e obtendo valores maiores do que os demais, apresentando um valor de $62,99 \%$, enquanto o tratamento GEL apresentou o segundo maior valor, $61,55 \%$, e o TRAD, com o menor teor de umidade, apresentou-se com $60,75 \%$, no nível de significância a 1\%. Para os queijos com 7 dias foram mantidas as mesmas posições porém não 
foram detectadas diferenças estatísticas significativas entre os tratamentos, mas somente tendências.

Os resultados do EST dos queijos com 1 dia vieram a corroborrar os resultados obtidos com o teor de umidade uma vez que são dados simétricos. $\mathrm{O}$ tratamento GE apresentou o menor EST (37,00\%), explicado pelo seu maior teor de umidade, que foi estatísticamente diferente dos tratamentos GEL $(38,45 \%)$ e TRAD (39,24\%), no nível de significância a $1 \%$. Nos queijos analisados com 7 dias o tratamento GE apresentou o menor valor porém sem ser observado estatisticamente.

\subsection{Rendimento}

De acordo com os resultados da Tabela 7, o tratamento GE apresentou uma média de rendimento de 17,09\%, isto é, com 6 litros de leite foram produzidos $1025,7 \mathrm{~g}$ de queijo, mostrando-se superior ao tratamento GEL que apresentou um rendimento de $16,18 \%$, ou a obtenção de $971,0 \mathrm{~g}$ de queijo para a mesma quantidade de leite, e também superior ao tratamento TRAD que com um rendimento de $16,07 \%$ proporcionou a obtenção de $965,0 \mathrm{~g}$ de queijo por 6 litros de leite.

TABELA 7 - Resultados de rendimento e peso dos queijos*.

\begin{tabular}{lcc}
\hline Tratamentos & Rendimento (\%) & Kgs de queijo/6 litros de leite \\
\hline TRAD & 16,07 & 0,965 \\
GE & 17,09 & 1,025 \\
GEL & 16,18 & 0,971 \\
\hline
\end{tabular}

*Médias de 5 repetições. 
Para os tratamentos GE e GEL, nos quais foram utilizadas as carragenas obteve-se os maiores rendimentos. Segundo GLICKSMAN (1983b), elas exibem uma interação eletrostática muito específica com as proteínas e com o cálcio formando complexos tridimensionais responsáveis pela textura e estabilização do leite. Têm a capacidade de formar estruturas de duplas hélices que durante o resfriamento originam uma rede polimérica tridimensional e exibem a capacidade de interagir com a água formando uma camada de solvatação que as envolve. Estes fenômenos explicam em parte o aumento do rendimento observado em relação ao queijo controle ou tratamento TRAD.

Este aumento no rendimento já foi observado anteriormente por WITT (1986) que obteve um rendimento de 10 a $17 \%$ com o uso de diferentes quantidades de carragenas na fabricação do queijo Cottage. BULLENS et al (1994) observaram aumentos no rendimento da fabricação de queijo Cheddar de até $10 \%$ em relação ao controle e atribuíram este fato a maior retenção de umidade pelo complexo caseína/carragena.

De acordo com a Tabela 7, ilustrada na Figura 6, os valores obtidos de rendimento para os três tratamentos situam-se dentro dos padrões préestabelecidos para este tipo de queijo (FURTADO et al, 1980a; FURTADO et al, 1980b). Apesar das médias apresentarem diferenças, estas não foram estatisticamente comprovadas, apenas confirmaram que existe uma tendência para um maior rendimento do tratamento GE em relação aos demais. 


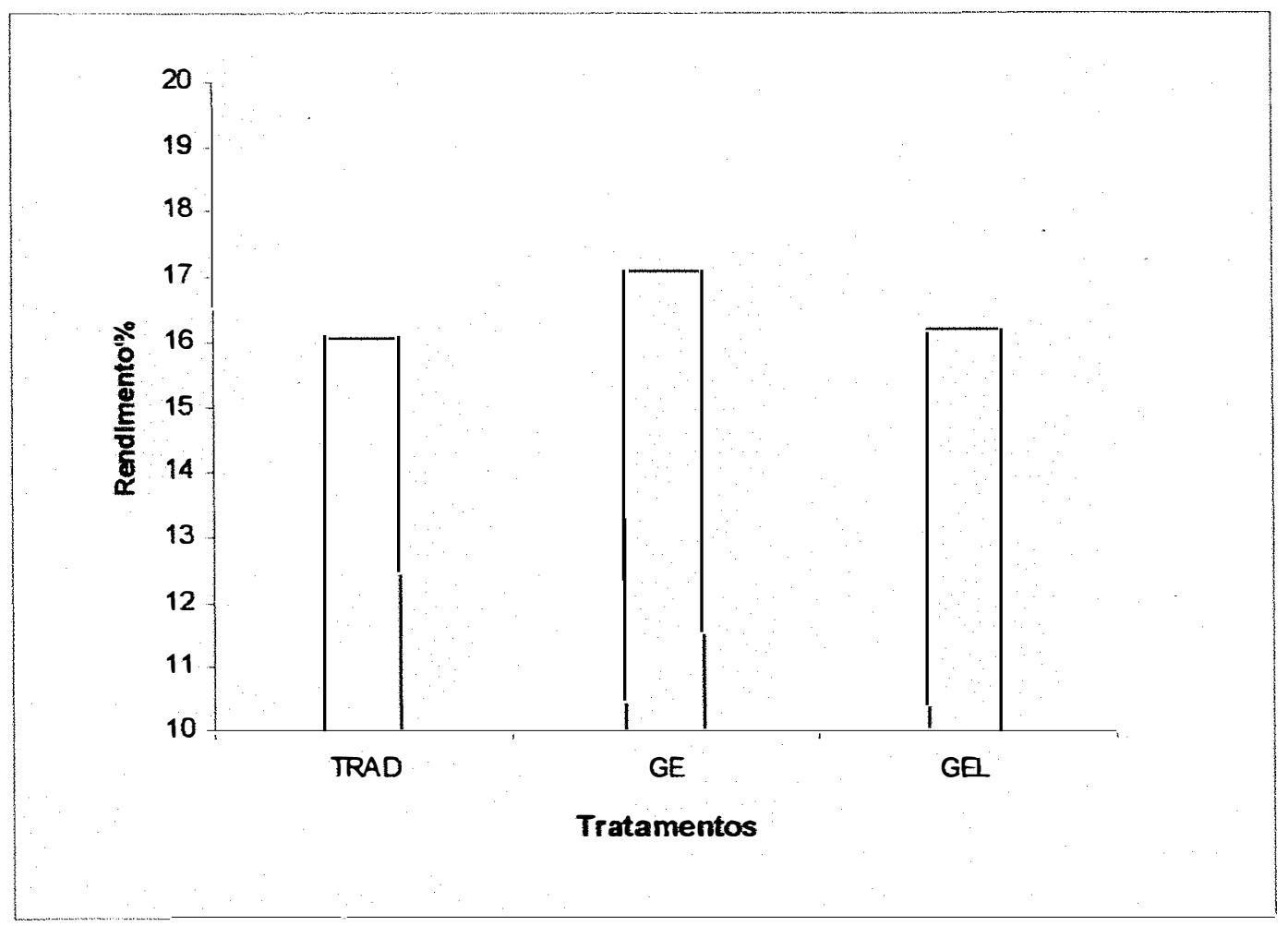

FIGURA 6- Rendimento dos queijos (médias de 5 repetições) 
Esta tendência de variação no rendimento da fabricação de queijo observada neste trabalho pode não ser significativa estatisticamente, mas no caso de uma produção industrial em larga escala, um pequeno acréscimo no rendimento poderá representar uma quantia considerável do ponto de vista econômico.

\subsection{Dessoragem}

Pela análise da Figura 7, que mostra a perda de peso dos queijos de cada tratamento durante os 7 dias de armazenamento, pode observar-se que os tratamentos GEL e TRAD tiveram um comportamento bastante semelhante enquanto o tratamento GE mostrou-se visivelmente diferente. Este tratamento, que teve o maior rendimento de fabricação, como pode ser observado na Figura 6, partiu de um peso inicial superior $(523,6 \mathrm{~g})$ aos outros tratamentos e ao final de 7 dias de armazenamento, no qual os queijos iam perdendo umidade, ainda apresentou o maior peso final $(416,8 \mathrm{~g})$ em média, em relação aos outros tratamentos. $\mathrm{O}$ tratamento GEL, segundo em rendimento e com uma média de peso inicial $(495,8 \mathrm{~g})$ ligeiramente superior ao TRAD $(491,9 \mathrm{~g})$, apesar de apresentar um comportamento bastante semelhante nos primeiros dias começou a diferenciar-se a partir do terceiro dia com uma tendência a estabilizar-se mantendo o seu peso mais ou menos constante enquanto que o tratamento TRAD continuava perdendo peso $(402,0 \mathrm{~g})$ e atingindo um peso inferior ao tratamento GEL $(407,8 \mathrm{~g})$. 


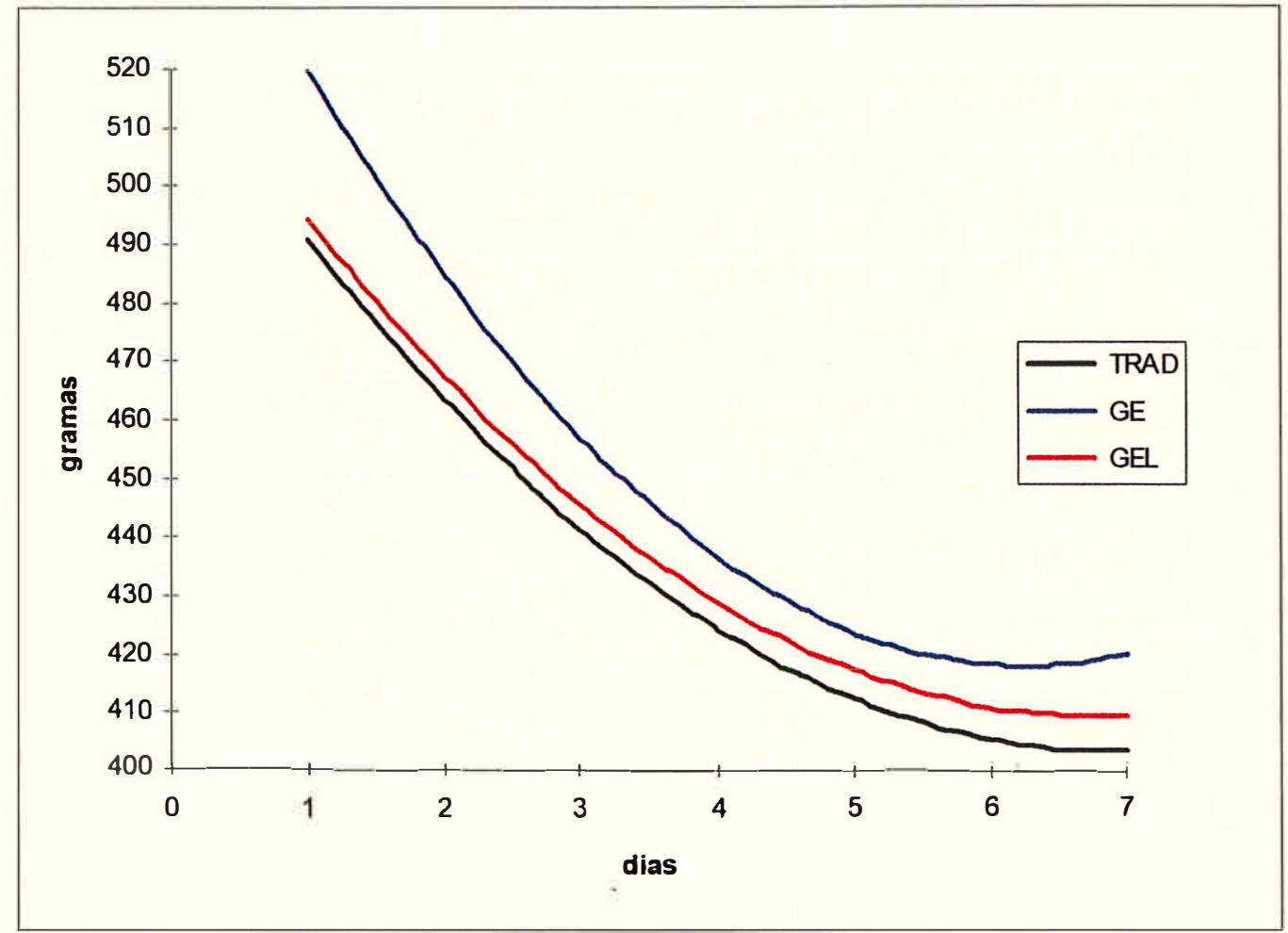

FIGURA 7 - Perda de peso para os três tratamentos durante os 7 dias de armazenamento (médias de 5 repetições). 
A Figura 8, que ilustra a dessoragem do queijo ao longo dos 7 dias pela perda de soro a cada dia, demonstra que o tratamento GE, apesar de apresentar o maior rendimento ao primeiro dia, foi também o que apresentou a maior perda de soro com o decorrer dos dias $(20,35 \%)$, mas ainda assim conseguiu manter-se com o maior rendimento ao final do armazenamento em relação aos outros tratamentos. O comportamento dos queijos dos outros tratamentos estão de acordo com a Figura 7 e mostraram-se com curvas semelhantes nos primeiros dias e mais ou menos a partir do terceiro dia diferenciaram-se, com o tratamento TRAD apresentando uma tendência maior ao dessoramento (18,27\%) e atingindo um total de perda de soro maior do que o do tratamento GEL, que apresentou os menores valores $(17,70 \%)$.

É provável que tenha sido perdida inicialmente pelos três tratamentos a água mais disponivel ou água livre, encerrada nas cavidades ou interstícios dos agregados micelares e expulsa mais rapidamente na dessoragem (WEBER, 1986). Esta perda foi ilustrada pela queda brusca do início da curva descendente apresentada pelos três tratamentos na Figura 7. Entre o terceiro e o quarto dia já foi possível detectar-se alguma diferença entre os tratamentos GEL e TRAD, que mais tarde definiriam suas tendências. Ao redor do sexto dia tornava-se menor a dessoragem nos três tratamentos e os queijos passaram a perder muito menos umidade em função do tempo. Este pode ter sido o ponto em que a água livre disponível esgotava-se e o peso dos queijos tendia a ser constante.

$\mathrm{O}$ tratamento GE, que apresentou o maior teor de umidade, mostrou também uma maior dessoragem, provavelmente por ter um maior volume de água livre retido para ser perdido. No sexto dia já apresentou uma dessoragem mínima e o peso dos queijos tendia a ser constante. Neste ponto a água livre já deveria ter sido quase toda perdida e fazia com que o peso dos queijos quase não sofresse 


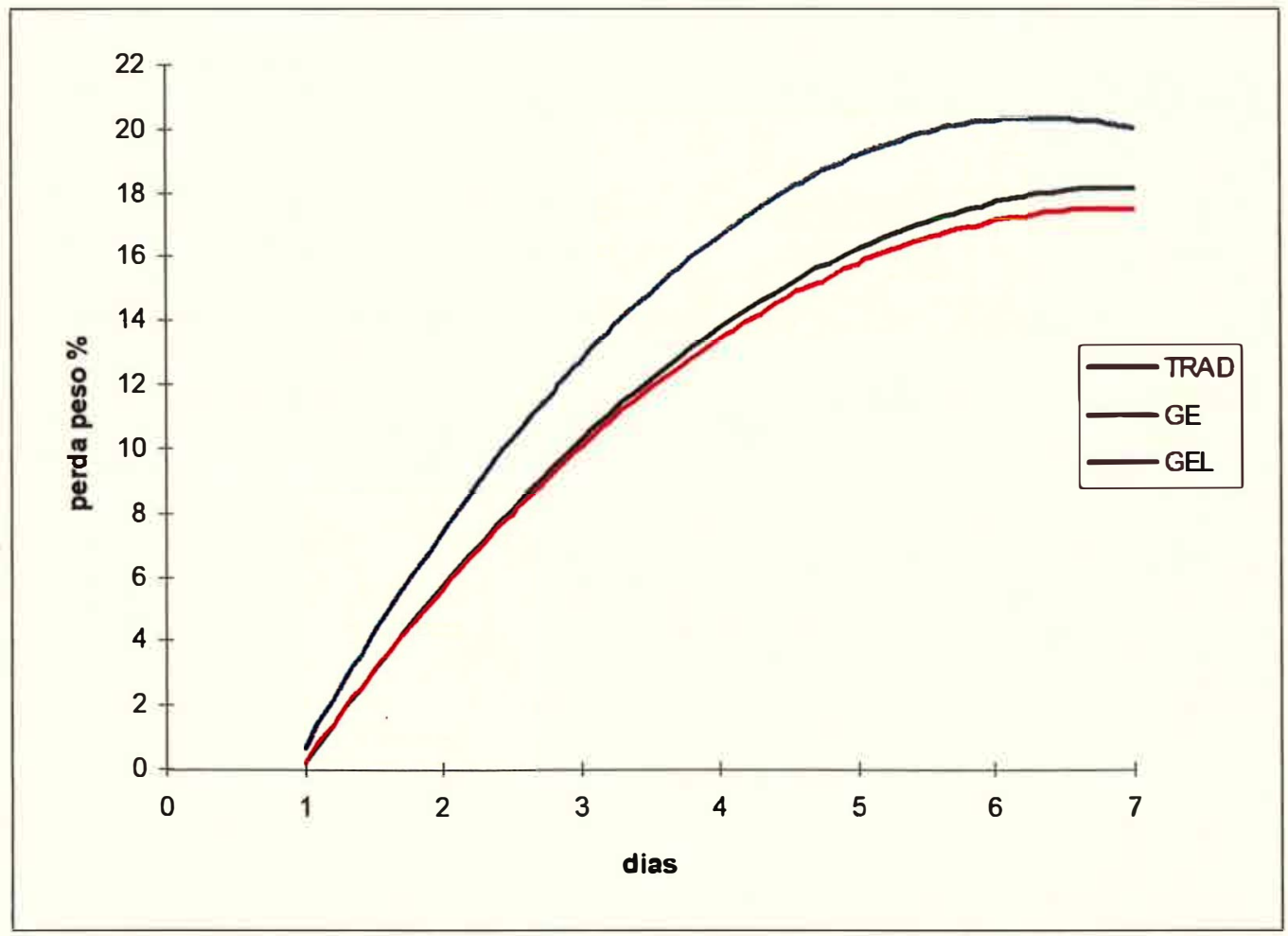

FIGURA 8 - Perda de peso\% para os três tratamentos durante os 7 dias de armazenamento (médias de 5 repetições). 
alterações. A umidade que continua retida no queijo, provavelmente a água capilar que não é eliminada por contração ou aquecimento do coágulo e que vai formar a reserva do queijo para a maturação, é mantida e determinará o teor de umidade e o rendimento do queijo (WEBER, 1986).

Os demais tratamentos tiveram um comportamento semelhante entre sí, com o GEL apresentando uma maior retenção de umidade e uma dessoragem ligeiramente inferior ao TRAD, provavelmente em função de apresentar a carragena na sua composição fazendo com que a água livre, e também a capilar, tenham sido mais firmemente retidas pela malha melhor estruturada do que o controle sem carragena, resultando num volume final de dessoragem ligeiramente inferior e apresentando um rendimento superior ao TRAD.

Para cada curva apresentada nas Figuras 7 e 8 existe uma equação de regressão e um coeficiente de deterninação que é apresentado nas Tabelas 8 e 9 . As equações de regressão entre a perda de peso e os dias mostraram uma estreita relação e altamente significativas, porém com os coeficientes de determinação $\left(R^{2}\right)$ não tão elevados quanto o das equações de regressão entre a perda de soro e os dias, que também mostraram-se com estreita relação e altamente significativas. 
TABELA 8 - Equações de regressão e coeficientes de determinação entre perda de peso e os dias.

\begin{tabular}{lcc}
\hline Tratamentos & \multicolumn{1}{c}{ Equação } & $\mathrm{R}^{2}$ \\
\hline TRAD & $\mathrm{y}=523,17-34,91 \mathrm{x}+2,54 \mathrm{x}^{2}$ & $0,743 * * *$ \\
GE & $\mathrm{y}=562,39-46,39 \mathrm{x}+3,72 \mathrm{x}^{2}$ & $0,738 * * *$ \\
GEL & $\mathrm{y}=526,47-34,72 \mathrm{x}+2,57 \mathrm{x}^{2}$ & $0,579 * * *$ \\
\hline$* * *(\mathrm{p}<0,001)$ & &
\end{tabular}

TABELA 9 - Equações de regressão e coeficientes de determinação entre perda de $\quad$ peso $\%$ e os dias.

\begin{tabular}{lcc}
\hline Tratamentos & \multicolumn{1}{c}{ Equação } & $\mathrm{R}^{2}$ \\
\hline TRAD & $\mathrm{y}=-6,35+7,07 \mathrm{x}-0,51 \mathrm{x}^{2}$ & $0,947^{* * *}$ \\
GE & $\mathrm{y}=-7,40+8,82 \mathrm{x}-0,70 \mathrm{x}^{2}$ & $0,908 * * *$ \\
GEL & $\mathrm{y}=-6,18+6,95 \mathrm{x}-0,51 \mathrm{x}^{2}$ & $0,866 * * *$ \\
\hline$* * *(\mathrm{p}<0,001)$ & &
\end{tabular}




\subsection{Análise Sensorial}

Os resultados obtidos para a análise sensorial dos queijos com 1 e 7 dias estão apresentados na Tabela 10.

TABELA 10 - Resultados da análise sensorial.

\begin{tabular}{lcccccc}
\hline & \multicolumn{6}{c}{ Respostas } \\
\cline { 2 - 7 } & \multicolumn{9}{c}{1 dia } & & & \\
& & \multicolumn{7}{c}{ dias } \\
Tratamentos & certas & erradas & total & certas & erradas & total \\
\hline GE X TRAD & 9 & 20 & 29 & 13 & 20 & 33 \\
GEL X TRAD & 11 & 18 & 29 & 13 & 20 & 33 \\
\hline
\end{tabular}

De acordo com MORAES (1993), com o número de respostas corretas e do total de provadores para cada teste realizado, apresentados na Tabela 10 determinou-se, por meio da Tabela 11 (apêndice), a não existência de diferenças estatísticas ao nível de significância a $1 \%$ entre os queijos provados que continham carragena (GE e GEL) quando comparados com os queijos controle (TRAD) nos testes realizados em queijos com 1 dia de fabricação e após 7 dias de armazenamento a $10^{\circ} \mathrm{C}$. $\mathrm{O}$ número mínimo de respostas corretas necessário para estabelecer-se diferença estatística nos níveis de significância a $0,1 \%, 1 \%$ ou $5 \%$ não foi atingido em nenhum dos testes. Resultados semelhantes foram obtidos por WITT (1986), que não detectou diferença no sabor e corpo do "Queso Blanco" elaborado com ou sem carragena. 
Estes resultados vêm a confirmar as expectativas dos fabricantes quando descrevem o produto como um pó homogêneo, insípido e inodoro (MORAIS et al, 1989) que não irá causar alterações sensoriais no produto final tendo em vista a sua baixa concentração no produto final. 


\section{CONCLUSÕES}

Os resultados obtidos na presente pesquisa sugerem as seguintes conclusões relativas a utilização das carragenas Gerba Nu-Kreme e Satiagel OF 10 BR na fabricação do queijo Minas Frescal:

O uso das carragenas não alteraram o processo da coagulação e nem a atividade da cultura lática;

O uso das carragenas não alterou a composição do queijo no que diz respeito a gordura e proteína mas permitiu uma maior retenção de umidade, com o tratamento GE apresentando um teor de umidade significativamente maior e um EST significativamente menor do que o controle;

O uso das carragenas permitiu um rendimento maior em comparação ao controle;

O uso das carragenas não provocou diferenças sensoriais nos queijos, observadas estatisticamente, quando comparados com o controle. 


\section{REFERÊNCIAS BIBLIOGRÁFICAS}

AKKERMAN, J. C.; FOX, F. H.; WALSTRA, P. Drainage of curd, expression of single curd grains. Netherlands Milk and Dairy Journal, Wageningen, $\underline{48}(1): 1-17,1994$.

AKKERMAN, J. C.; LEWIS, R O.; WALSTRA, P. Fusion of curd grains. Netherlands Milk and Dairy Journal, Wageningen, 47(3/4):121-35, 1993.

ANTUNES, A. J. \& CANHOS, V. P. Espessantes e estabilizantes. In:------Aditivos em alimentos. São Paulo, Secretaria da Indústria e Comércio, Ciência e Tecnologia, 1987. cap.3, p.32-66.(Série Difusão Agroindustrial, $6)$.

ASSOCIATION OF OFFICIAL ANALYTICAL CHEMISTS. Official methods of analysis. 15. ed. Washington, 1990. 2v.

BEHMER, M. Análises principais do leite. In:-------Tecnologia do leite. São Paulo, Nobel, 1991. cap.13, p. 105. 
BLANQUAT, G. de S. \& KLEIN, D. Evaluation toxicologique des carraghénanes. Effets nutrittionnels et digestifs. Science des Aliments, Paris, $4(3): 375-88,1984$.

BULLENS, C.; KRAWCZYK, G.; GEITHMAN, L. Reduced-fat cheese products using carrageenan and microcrystalline cellulose. Food Technology, Chicago, 48(1):79-81, Jan. 1994.

BRUMMEL, S. E. \& LEE, K. Soluble hydrocolloids enable fat reduction in process cheese spreads. Journal of Food Science, Chicago, 55(5): 1290-2, Sept./Oct., 1990.

CARVALHO, I. C. Modificações na composição do leite. Revista do Instituto Cândido Tostes, Juiz de Fora, 32(192):15-22, jul./ago. 1977.

DUMAS, R.; BLAIS, J. A.; CONRAD, F. Queso. In: AMIOT, J. Ciencia y tecnologia de la leche. Zaragoza, Acribia, 1991. cap.9, p.249-96.

FAO. Quaterly bulletin of statistics. Rome, 1995. p.42, v. 8.

FURTADO, M. M. A arte e a ciência do queijo. 2.ed. São Paulo, Globo, 1990. $297 p$.

FURTADO, M. M. Tecnologia de fabricação de queijos. s.n.t. 1975. 
FURTADO, M. M. \& LOURENÇO-NETO, J. P. de M. Tecnologia de queijos; manual técnico para a produção industrial de queijos. São Paulo, Dipemar, 1994. p.73-5.

FURTADO, M. M. \& WOLFSCHOON-POMBO, A. F. Fabricação de queijo Prato e Minas. Estudo do rendimento. Parte 1: determinação das cifras de transição. Revista do Instituto Cândido Tostes, Juiz de Fora, 34(205): 320, set./out. 1979 a.

FURTADO, M.M. \& WOLFSCHOON-POMBO, A. F. Fabricação de quejo Prato e Minas. Estudo do rendimento. Parte 2: previsão da gordura no extrato seco. Revista do Instituto Cândido Tostes, Juiz de Fora, 34(206):3-14, nov./dez. 1979b.

FURTADO, M. M. \& WOLFSCHOON-POMBO, A. F. Perda de umidade da coalhada durante a fabricação do queijo Prato. Revista do Instituto de Laticínios Cândido Tostes, Juiz de Fora, 38(229):3-6, set./out. 1983.

FURTADO, M. M.; SOUZA, H. M. de; MUNCK, A. V. Fabricação de queijo minas frescal sem o emprego de culturas láticas. Revista do Instituto

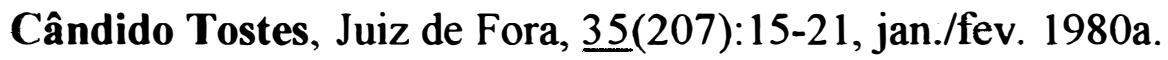

FURTADO, M. M.; WOLFSCHOON-POMBO, A. F.; MUNCK, A. V.; SOUZA, H. M. de Estudo conclusivo à respeito da fabricação do queijo Minas Frescal por diferentes processos. Revista do Instituto Cândido Tostes, Juiz de Fora, $\underline{35}$ (208):13-8, mar./abr. 1980b. 
GARCIA, S. R. Carragenas e pectinas: aplicação em laticínios. Leite \& Derivados, São Paulo, 4(23):47-8, jul./ago. 1995.

GLICKSMAN, M. Origins and classification of hydrocolloids. In: --------Food hydrocolloids. Boca Raton, CRC Press, 1982. v.1, part.1, cap. 1, p. 3-18.

GLICKSMAN, M. Introduction. In:-------Food hydrocolloids. Boca Raton, CRC Press, 1983a. v.2, part.2, p.63-71.

GLICKSMAN, M. Red seaweed extracts (agar, carrageenans, furcelaran). In:-------Food hydrocolloids. Boca Raton, CRC Press, 1983b. v.2, part.2, cap.5, p.74-113.

GREEN, M. L. \& GRADISON, A. S. Secondary (non-enzimatic) phase of rennet coagulation and post-coagulation phenomena. In: FOX, P. F. ed. Cheese: chemistry, physics and microbiology. Essex, Elsevier, 1987. v.1, cap.4, p.97-135.

INTERNATIONAL DAIRY FEDERATION. Determination of the total nitrogen content of milk by the Kjeldahl method. FIL-IDF, Brussels, 20:1-3, 1962.

KEATING, P. F. Bases tecnicas de la fabricacion del queso. In:---.--Introduccion a la lactologia. Monterrey, Instituto Tecnologico y de Studios Superiores, 1969. cap.9, p.26-9. 
LANARA. Métodos analíticos oficiais para controle de produtos de origem animal e seus ingredientes. Métodos fisicos e químicos. Brasília, 1981. p.irreg.

LABLEÉ, J. Technical faults in coagulation and drainage. In: ECK, A. ed. Cheese making, science and technology. New York, Lavoisier Publ., 1986. part.2, cap.7, p.193-202.

LOCALLIER, P. R. As carragenas. In: CONGRESSO NACIONAL DE LATICÍNIOS, 4., Juiz de Fora, 1977. Anais. Juiz de Fora, ILCT/CEPE/EPAMIG, 1977. p.341-52.

LORENA, W. \& FERREIRA, A. F. S. O uso de gomas e espessantes em alimentos. Alimentos e Bebidas, São Paulo, 1(4):11-6, jun./jul. 1989.

MARTIN, G. Evaluation toxicologique des carraghènanes. definition, structure, fabrication, propriétés et applications. Sciences des Aliments, Paris, $4(3): 335-46,1984$.

MORAES, M. A. C. Métodos para avaliação sensorial dos alimentos. 8.ed. Campinas, Unicamp, 1993. 93p.

MORAIS, C. de ; VAlLE, J. L. E. do ; PIZZINATTO, A. Colóides de algas marinhas. 2. considerações sobre as carragenanas. Coletânea do Instituto de Tecnologia de Alimentos, Campinas, 1(19):12-24, 1989. 
NEWLANDER, J. A. \& ATHERTON, H. V. Babcock, Gerber, Monjonier tests for fat. In:------The chemistry and testing of dairy products. Milwaukee, Olsen Publ., 1964. cap.4, p.67-114.

NOËL, Y.; RAMET, J. P.; GERVAIS, A.; LABLEÉ, J.; CERF, O. Physical properties of the coagulum. In: ECK, A. ed. Cheese making, science and technology. New York, Lavoisier Publ., 1986. cap.8, p.206-18.

OLIVEIRA, J. S. de. Fabricação dos principais queijos. In:--------Queijo: fundamentos tecnológicos. São Paulo, Ícone, 1986. cap.6, p.105-45.

ORGANIZATION MONDIALE DE LA SANTÉ. Evaluation toxicologique de certains additifs alimentaires et notamment d'antiagglutinants, d'antimicrobiens, d'antioxygènes, d'emulsifiants et d'epaississants. 1976. (Série Additifs Alimentaires, 5).

PIMENTEL GOMES, F. Curso de estatística experimental. São Paulo, Nobel, 1985. 466p.

REDDY, B. S.; WATANABE, K.; SHEINFIL, A. Effect of dietary wheat bran, alfafa, pectin and carrageenan on plasma cholesterol and fecal bile acid and neutral sterol excretion in rats. Journal of Nutrition, Philadelphia, 110:1247-54, 1980.

RENDIMENTO da fabricação de queijos. Leite \& Derivados, São Paulo, 2(10):39-40, mai./jun.1993. 
SAITO, T. \& SCHIFTAN, Z. T. Estudos da composição de queijo Minas Frescal, fabricado no Estado de São Paulo. Revista do Instituto de Laticínios Cândido Tostes, Juiz de Fora, 33(199):29-37, set./out. 1978.

SANTIAGO, O. Aditivos em laticínios e derivados. Revista do Instituto de Laticínios Cândido Tostes, Juiz de Fora, 26(154/5):1-3, jan/abr. 1971.

SIMÃO, A. M. Gomas. In:--------Aditivos para alimentos sob o aspecto toxicológico. São Paulo, Nobel, 1985. cap.8, p.131-2.

VASSAL, L. The sensory analysis of cheese. In: ECK, A. ed. Cheesemaking: science and technology. New York, Lavoisier, 1987. cap.25, p.489-99.

WALSTRA, P.; van DIJK, H. J. M.; GEURTS, T. J. The syneresis of curd. 1. General considerations and literature review. Netherlands Milk and Dairy Journal, Wageningen, 39(4):209-46, 1985.

WEBER, F. Curd drainage In: ECK, A. ed. Cheese making, science and technology. New York, Lavoisier Publ., 1986. Part.1, cap.2, p.22-34.

WHISTLER, R. L.; DANIEL, J. R. Carbohydrates. In: FENEMA, O. R. ed. Food chemistry. 2.ed. New York, Marcel Dekker, 1985. cap. 3, p. 129130.

WHITEHEAD, H. R. Control of the moisture content and "body firmness" of cheddar cheese. The Journal of Dairy Research, Cambridge, 15(3):38797, May. 1948. 
WITT, H. J. Method for making cheese using carrageenan. Patente industrial (Estados Unidos), n ${ }^{\circ}$ WO 86/00786. 1986.

WOLFSCHOON-POMBO, A. F. \& FURTADO, M. M. Composição média do soro de queijo Prato e Minas. Revista do Instituto Cândido Tostes, Juiz de Fora, $\underline{32}(194): 21-6$, nov./dez. 1977.

WONG, N. P. Cheese chemistry. In: WEBB, B. H. ed.; JOHNSON, A. H.; ALFORD, J. A. Fundamentals of dairy chemistry. 2.ed. Westport, AVI Publ., 1974. cap.2, part.2, p.719-71. 
APÊNDICE 
FORMULÁRIO . 1 - avaliação do Teste Triangular

NOME:

DATA: 11

Duas amostras são iguais e uma é diferente. Coloque um círculo ao redor da amostra diferente em cada grupo.

Grupo Amostras

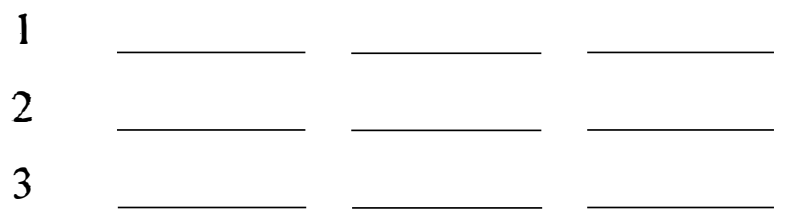

Comentários: se sentiu alguma diferença, dizer em que aspecto. 
TABELA 11

Significância no teste triangular $(\mathrm{P}=1 / 3)$

\begin{tabular}{|c|c|c|c|}
\hline \multirow[t]{2}{*}{$\begin{array}{c}\mathrm{n}^{\circ} \mathrm{de} \\
\text { julgamentos }\end{array}$} & \multicolumn{3}{|c|}{$\begin{array}{c}\mathrm{n}^{\circ} \text { de respostas corretas necessárias } \\
\text { para estabelecer diferença } \\
\text { significativa }\end{array}$} \\
\hline & $\mathrm{P}=0,05$ & $\mathrm{P}=0,01$ & $\mathrm{P}=0,001$ \\
\hline 20 & 11 & 13 & 14 \\
\hline 21 & 12 & 13 & 15 \\
\hline 22 & 12 & 14 & 15 \\
\hline 23 & 13 & 14 & 16 \\
\hline 24 & 13 & 14 & 16 \\
\hline 25 & 13 & 15 & 17 \\
\hline 26 & 14 & 15 & 17 \\
\hline 27 & 14 & 16 & 18 \\
\hline 28 & 15 & 16 & 18 \\
\hline 29 & 15 & 17 & 19 \\
\hline 30 & 16 & 17 & 19 \\
\hline 31 & 16 & 18 & 19 \\
\hline 32 & 16 & 18 & 20 \\
\hline 33 & 17 & 19 & 20 \\
\hline 34 & 17 & 19 & 21 \\
\hline 35 & 18 & 19 & 21 \\
\hline 36 & 18 & 20 & 22 \\
\hline 37 & 18 & 20 & 22 \\
\hline 38 & 19 & 21 & 23 \\
\hline 39 & 19 & 21 & 23 \\
\hline 40 & 20 & 22 & 24 \\
\hline
\end{tabular}

Fonte: MORAES (1993) 
Análise Estatística dos dados obtidos a partir dos queijos analisados com 1 dia:

QUADRO 1 - Análise de variância para os dados obtidos de proteína.

\begin{tabular}{lllll}
\hline Causas de variação & G.L. & Q.M. & F & Prob > \\
F & & & & \\
Tratamentos & 2 & 2,399 & 0,91 & 0,4109 \\
Residuo & 42 & 2,641 & & \\
\hline Total & 44 & & & \\
C.V. & $11,31 \%$ & & & \\
\hline
\end{tabular}

QUADRO 2 - Análise de variância para os dados obtidos de gordura.

\begin{tabular}{lllll}
\hline Causas de variação & G.L. & Q.M. & F & Prob > \\
F & & & & \\
Tratamentos & 2 & 3,966 & 1,59 & 0,2165 \\
Residuo & 42 & 2,499 & & \\
\hline Total & 44 & & & \\
\hline C.V. & & & & \\
\hline
\end{tabular}


QUADRO 3 - Análise de variância para os dados obtidos de umidade.

\begin{tabular}{lllll}
\hline Causas de variação & G.L. & Q.M. & F & Prob > \\
F & & & & \\
\hline Tratamentos & 2 & 19,395 & 6,78 & 0,0028 \\
Residuo & 42 & 2,858 & & \\
\hline Total & 44 & & & \\
\hline C.V. & & & & \\
\hline
\end{tabular}

QUADRO 4 - Resultados da aplicação do teste de Tuckey para as médias de 15 repetições dos tratamentos da variável umidade.

\begin{tabular}{lcc}
\hline Tratamento & Médias & $1 \%$ \\
& & $\mathrm{a}$ \\
Ge & 62,997 & $\mathrm{ab}$ \\
Gel & 61,551 & $\mathrm{~b}$ \\
Trad & 60,753 & \\
& & \\
\hline
\end{tabular}

Médias seguidas por letras distintas diferem entre sí ao nível de significância a $1 \%$. D.M.S. $1 \%=1,9011 \%$

QUADRO 5 - Análise de variância para os dados obtidos de EST.

\begin{tabular}{lllll}
\hline Causas de variação & G.L. & Q.M. & F & Prob > \\
F & & & & \\
\hline Tratamentos & 2 & 19,348 & 6,76 & 0,0028 \\
Residuo & 42 & 2,861 & & \\
& & & & \\
\hline Total & 44 & & & \\
C.V. & $4,42 \%$ & & & \\
\hline
\end{tabular}


QUADRO 6 - Resultados da aplicação do teste de Tuckey para as médias de 15 repetições dos tratamentos da variável EST.

\begin{tabular}{lcc}
\hline Tratamento & Médias & $1 \%$ \\
\hline Trad & 39,246 & $\mathrm{a}$ \\
Gel & 38,449 & $\mathrm{ab}$ \\
Ge & 37,005 & $\mathrm{~b}$
\end{tabular}

Médias seguidas por letras distintas diferem entre sí ao nível de significância a $1 \%$. D.M.S. $1 \%=1,9019 \%$

QUADRO 7 - Análise de variância para os dados obtidos de GES.

\begin{tabular}{lllll}
\hline Causas de variação & G.L. & Q.M. & F & Prob $>$ \\
F & & & & \\
\hline $\begin{array}{l}\text { Tratamentos } \\
0,9626\end{array}$ & 2 & 0,544 & 0,04 & \\
Residuo & 42 & 14,266 & \\
\hline Total & 44 & & \\
C.V. & $7,95 \%$ & & \\
\hline
\end{tabular}

QUADRO 8 - Análise de variância para os dados obtidos de rendimento.

\begin{tabular}{lcccc}
\hline Causas de variação & G.L. & Q.M. & F & Prob > \\
F & & & & \\
Tratamentos & 2 & 1,566 & 1,65 & 0,2322 \\
Residuo & 12 & 0,947 & & \\
\hline Total & 14 & & & \\
C.V. & $5,91 \%$ & & & \\
\hline
\end{tabular}


QUADRO 9 - Análise de variância para os dados obtidos de acidez.

\begin{tabular}{lllll}
\hline Causas de variação & G.L. & Q.M. & F & Prob $>$ \\
F & & & & \\
\hline Tratamentos & 2 & 0,000 & 0,08 & 0,9274 \\
Resíduo & 12 & 0,001 & & \\
\hline Total & 14 & & & \\
C.V. & $15,67 \%$ & & & \\
\hline
\end{tabular}

QUADRO 10 - Análise de variância para os dados obtidos de pH.

\begin{tabular}{lcccc}
\hline Causas de variação & G.L. & Q.M. & F & Prob $>$ \\
F & & & & \\
\hline Tratamentos & 2 & 0,001 & 0,02 & 0,9846 \\
Resíduo & 12 & 0,067 & & \\
\hline Total & 14 & & & \\
C.V. & $5,53 \%$ & & &
\end{tabular}


Análise Estatística dos dados obtidos a partir dos queijos analisados com 7 dias:

QUADRO 11 - Análise de variância para os dados obtidos de proteína.

\begin{tabular}{lllll}
\hline Causas de variação & G.L. & Q.M. & F & Prob > \\
F & & & & \\
Tratamentos & 2 & 3,191 & 2,86 & 0,0684 \\
Resíduo & 42 & 1,115 & & \\
\hline Total & 44 & & & \\
C.V. & $6,45 \%$ & & & \\
\hline
\end{tabular}

QUADRO 12 - Análise de variância para os dados obtidos de gordura.

\begin{tabular}{lllll}
\hline $\begin{array}{l}\text { Causas de variação } \\
\text { F }\end{array}$ & G.L. & Q.M. & F & Prob > \\
Tratamentos & 2 & 2,090 & 0,62 & 0,5411 \\
Resíduo & 42 & 3,354 & & \\
Total & 44 & & & \\
C.V. & $8,34 \%$ & & & \\
\hline
\end{tabular}


QUADRO 13 - Análise de variância para os dados obtidos de umidade.

\begin{tabular}{lcccc} 
Causas de variação & G.L. & Q.M. & F & Prob > \\
F & & & & \\
\hline Tratamentos & 2 & 7,410 & 3,00 & 0.0608 \\
Resíduo & 42 & 2,473 & & \\
\hline Total & 44 & & & \\
\hline C.V. & $2,82 \%$ & & & \\
\hline
\end{tabular}

QUADRO 14 - Análise de variância para os dados obtidos de EST.

\begin{tabular}{lllll}
\hline Causas de variação & G.L. & Q.M. & F & Prob > \\
F & & & & \\
Tratamentos & 2 & 8,542 & 3,45 & 0,0409 \\
Resíduo & 42 & 2,473 & & \\
\hline Total & 44 & & & \\
\hline C.V. & $3,54 \%$ & & & \\
\hline
\end{tabular}

QUADRO 15 - Análise de variância para os dados obtidos de GES.

\begin{tabular}{lllll}
\hline Causas de variação & G.L. & Q.M. & F & Prob > \\
F & & & & \\
Tratamentos & 2 & 2,697 & 0,24 & 0,7908 \\
Resíduo & 42 & 11,427 & & \\
\hline Total & 44 & & & \\
\hline C.V. & $6,84 \%$ & & & \\
\hline
\end{tabular}


QUADRO 16 - Análise de variância para os dados obtidos de acidez.

\begin{tabular}{lcccc}
\hline Causas de variação & G.L. & Q.M. & F & Prob $>$ \\
F & & & & \\
\hline Tratamentos & 2 & 0,000 & 0,54 & 0,5985 \\
Resíduo & 12 & 0,000 & & \\
\hline Total & 14 & & & \\
\hline C.V. & $10,40 \%$ & & & \\
\hline
\end{tabular}

QUADRO 17 - Análise de variância dos dados obtidos de pH.

\begin{tabular}{lcccc}
\hline $\begin{array}{l}\text { Causas de variação } \\
\text { F }\end{array}$ & G.L. & Q.M. & F & Prob $>$ \\
Tratamentos & 2 & 0,001 & 0,09 & 0,9134 \\
Resíduo & 12 & 0,014 & & \\
\hline Total & 14 & & & \\
\hline C.V. & $2,66 \%$. & & & \\
\hline
\end{tabular}


Quadros de análise de variância para as equações de regressão referentes aos gráficos de perda de peso e dessoragem:

QUADRO 18 - Análise de variância para equação de regressão do gráfico de perda de peso para o tratamento TRAD.

\begin{tabular}{lcccc}
\hline Causas de variação & G.L. & Q.M. & F & Prob > \\
F & & & & \\
\hline Regressão & 2 & 16196,56 & 46,45 & 0,0001 \\
Resíduo & 32 & 348,72 & & \\
\hline Total & 34 & & & \\
\hline C.V. & $4,29 \%$. & & & \\
\hline
\end{tabular}

QUADRO 19 - Análise de variância para equação de regressão do gráfico de perda de peso para o tratamento GE .

\begin{tabular}{lcccc}
\hline Causas de variação & G.L. & Q.M. & F & Prob > \\
F & & & & \\
\hline Regressão & 2 & 22248,61 & 45,13 & 0,0001 \\
Residuo & 32 & 492,96 & & \\
\hline Total & 34 & & & \\
\hline C.V. & $4,92 \%$. & & & \\
\hline
\end{tabular}


QUADRO 20 - Análise de variância para equação de regressão do gráfico de perda de peso para o tratamento GEL.

\begin{tabular}{lcccc}
\hline Causas de variação & G.L. & Q.M. & F & Prob > \\
F & & & & \\
\hline Regressão & 2 & 15356,85 & 22,03 & 0,0001 \\
Resíduo & 32 & 697,16 & & \\
\hline Total & 34 & & & \\
\hline C.V. & $6,01 \%$. & & & \\
\hline
\end{tabular}

QUADRO 21 - Análise de variância para equação de regressão do gráfico de perda de peso \% para o tratamento TRAD.

\begin{tabular}{lllll}
\hline Causas de variação & G.L. & Q.M. & F & Prob > \\
F & & & & \\
Regressão & 2 & 669,81 & 287,76 & 0,0001 \\
Resíduo & 32 & 2,32 & & \\
\hline Total & 34 & & & \\
C.V. & $13,07 \%$. & & & \\
\hline
\end{tabular}

QUADRO 22 - Análise de variância para equação de regressão do gráfico de perda de peso \% para o tratamento GE.

\begin{tabular}{lcccc}
\hline Causas de variação & G.L. & Q.M. & F & Prob > \\
F & & & & \\
Regressão & 2 & 811,14 & 159,81 & 0,0001 \\
Residuo & 32 & 5,07 & & \\
\hline Total & 34 & & & \\
C.V. & $16,35 \%$. & & & \\
\hline
\end{tabular}


QUADRO 23 - Análise de variância para equação de regressão do gráfico de perda de peso $\%$ para o tratamento GEL.

\begin{tabular}{lcccc}
\hline Causas de variação & G.L. & Q.M. & F & Prob > \\
F & & & & \\
Regressão & 2 & 625,51 & 103,56 & 0,0001 \\
Resíduo & 32 & 6,04 & & \\
\hline Total & 34 & & & \\
\hline C.V. & $21,59 \%$. & & & \\
\hline
\end{tabular}

